\title{
Chronic inflammation evoked by pathogenic stimulus during carcinogenesis
}

\author{
Björn L.D.M. Brücher ${ }^{1,2,3, *}$, Ijaz S. Jamall ${ }^{1,2,4}$ \\ ${ }^{1}$ Theodor-Billroth-Academy ${ }^{\circledR}$, Germany, USA \\ 2 INCORE, International Consortium of Research Excellence of the Theodor-Billroth-Academy ${ }^{\circledR}$, Germany, USA \\ ${ }^{3}$ Department of Surgery, Carl-Thiem-Klinikum, Cottbus, Germany \\ ${ }^{4}$ Risk-Based Decisions Inc., Sacramento, CA, USA
}

Received 21 March 2018, Accepted 21 November 2018

\begin{abstract}
A pathogenic (biological or chemical) stimulus is the earliest information received by a cell that can result in the disruption of homeostasis with consequent development of disease. Chronic inflammation involves many cell types with numerous cytokines and signaling pathways, the release of different components by the cells, and the crosstalk provoked by such stimuli involving subclinical chronic inflammation and is mechanistically manifold. Exosomes secrete chemicals that trigger the epithelium to produce exosome-like nanoparticles promoting chronic inflammation. Small molecules, together with various cytokines, selectively target signaling pathways inducing crosstalk that suppress apoptosis. 16S rRNA gene sequencing has become routine to provide information on the composition and abundance of bacteria found in human tissues and in reservoirs. The deregulation of autophagy with chronic stimulation of inflammation is an early phenomenon in carcinogenesis. The disruption of cell-cell integrity enables transcellular CagA migration and triggers deregulation of autophagy with the net result being chronic inflammation. The complex and insidious nature of chronic inflammation can be seen both inside and outside the cell and even with intracellular nuclear fragments such as chromatin, which itself can elicit a chronic inflammatory response within the cytoplasm and affect autophagy. The ultimate result of unresolved chronic inflammation is fibrosis, a step before tissue remodeling results in the formation of a precancerous niche $(\mathrm{PCN})$. Various pathogenic stimuli associated with different neoplasms result in persistent inflammation. This ongoing disruption of homeostasis in the micromilieu of cells, tissues, and organs is an essential preamble to carcinogenesis and occurs early in that process.
\end{abstract}

Keywords: Adenoma, Adhesion, Akt, ALOX, Apoptosis, Aquaporin, Autophagy, Bacterium, BIM, Blastoma, Cancer, Carcinoma, Carcinogenesis, CCC, Cdc42, Cdk2, Cholangiocellular carcinoma, Crohn's disease, Chronic inflammation, Colitis, Colorectal cancer, COX, Cyclin, Cyclooxygenase, CYP, Cytochrome P450, Cytokine, CXCR4, E2F4/5, E-cadherin, Eicosanoide, EBV, Epstein-Barr virus, ERK, ETE, Fibroblast, Fibrosis, Fluke, FOXO3a, Gastric cancer, Gastritis, Glycocalyx, HBV, HCV, Helicobacter pylori, Hepatitis B virus, Hepatitis C virus, HETE, Homeostasis, HCC, HIV, HPV, HSV, Human herpes virus, Human papilloma virus, IBD, ICAM, IDO, IL, IL- $\beta 1$, Interleukin, Inflammation, Leukemia, Lipoxygenase, LTA4, LTB4, LTC4, LTD4, LTE4, Liver cancer, LOX, LOXL3, Lymphoma, Lysyl oxidase, MAPK, MDA, Metalloproteinase, MMP, Mutation, NF-кB, AP1, API2, PCN, PGD2, PGG2, PGH2, PGFF2a, Phagocytes, PI3K, Polyp, Precancerous niche, Prostate cancer, PUMA, Rac1, RNS, ROS, Sarcoma, SPhK, S1P, S1PR3, Simvastatin, SK2, SOX, Tissue, TGF, TNF, TOR, TXA2, VCAM, Virus, VZV

\section{Introduction}

Inflammation associated with cancer dates back to the British physician Sir Percival Pott (1714-1788), who reported chronic inflammation in testicular cancer in chimney sweeps in 1755 [1]. In 1829, William Edmonds Horner (1793-1853) described how chronic inflammation

\footnotetext{
*Corresponding author: b-bruecher@gmx .de
}

follows unresolved acute inflammation [2]. The French physiologist, Henri Dutrochet (1776-1847), reported how cells migrate to sites of inflammation [3]. In 1843, an experimental injury-induced diapedesis was shown by William Addison (1802-1881) [4], which was followed by the British physiologist, August Volney Waller (18161870) in 1846, who observed colorless blood cells in intact capillaries within frog tongue and mesentery [5]. In 1857, Brown reported acute (and chronic) inflammation 
induced by the topical application of arsenic in a patient [6].

Rudolf Virchow reported leukocytes in cancer tissues [7] and his pupil, the German-Jewish pathologist, Julius Friedrich Cohnheim (1839-1884), showed that colorless blood corpuscules migrated from vessels into inflammatory tissue and named these cells Eiterkörperchen (puscorpuscles) [8,9], which resulted into the so-called migration theory and introduced a renaissance in the theory of inflammation. In contrast to his teacher Rudolf Virchow, Cohnheim found that "the leukocytes found in inflammation are predominantly derived from the blood by diapedesis through the capillary walls" (reviewed in Ref. [10]).

In 1868, the British Surgeon Thomas Bryant reported 10 cases of chronic inflammation in female breast cancer patients [11]. His fifth case was a 48-year-old female who presented with a history of earlier abscess and chronic inflammation of her right breast, which he was suspected of having cancer. Treatment against inflammation with tonic was successful but the patient developed contralateral breast cancer a year later. In 1891, Frederic S. Eve reported a 48-year male with chronic inflammation and tongue cancer with "chronic superficial glossitis for years" and a sore tongue for some 10 years [12].

Cohnheim's leukocytes migration was proven by the Virchow's pupil, Julius Arnold (1835-1915) in 1873 [13-15]. In 1883, the Russian Zoologist Elias Metschnikoff (1845-1916, also Ilya Ilyich Mechnikov from the Russian: Илья Ильич Мечников) observed phagocytic cells surrounding rose thorns stuck into starfish larvae as a host defense $[16,17]$ : the phagocyte doctrine was born after Mechnikov's friend, Karl Claus, coined the term phagocytes. Metschnikoff was awarded the Nobel Prize in 1908. Various cell types during those early days had to be discovered, which may explain the difficulty to diagnose chronic inflammation-induced breast cancer [11].

Today we know that inflammation is a complex mechanism as any kind of stimulus appears to induce inflammation. The following is divided into pathogenic stimulus including viruses, bacteria, and fluke, followed by the newly described aquaporins (APQ) and autophagy followed by a section on chronic inflammation.

\section{Pathogenic stimulus}

A pathogenic (chemical or biological) stimulus is the earliest information a cell receives that can trigger the six sequential steps that lead to cancer $[18,19]$. The role of chemical carcinogens in the tumor microenvironment and carcinogenesis had earlier been reviewed. There is no published study wherein chemical carcinogens have been shown to induce somatic mutations and those mutations have led directly to the onset of cancers.

In fact, most studies on chemical carcinogenesis require a long latency period between repeated exposures to the carcinogen and the onset of cancer [20]. The reason for the latency period is the necessity of chronic inflammation and fibrosis with their associated changes in signaling that leads to the onset of cancer. It seems rather logical to combine results of observations in biology that the onset of cancer involves a pathogenic stimulus, followed (if unresolved) by chronic inflammation, fibrosis, and a disruption of homeostasis such that cancer can result over decades in a subset of the exposed population [18,19].

The fact that somatic mutations are detected at certain time points, post-exposure to chemical carcinogens $[21,22]$, merely suggests that such mutations are epiphenomena or incidental to carcinogenesis and not necessarily causal to the onset of cancer as explained elsewhere $[18,19,23]$.

For example, chronic exposure to certain asbestos fibers results in pleural mesothelioma but with no mutations [24]. Carbon tetrachloride causes inflammation, fibrosis of the liver, and later hepatic carcinoma [25]. Hepatitis $\mathrm{C}$ in humans causes chronic inflammation with liver fibrosis, cirrhosis, and some $30 \%$ of patients with cirrhosis go on to develop hepatocellular carcinoma (HCC) with no mutations [26]. This is also true in the case of Human Papilloma virus (HPV) and cervical or oropharyngeal cancers with chronic inflammation but no somatic mutations [27-30]. Although we all acknowledge that chronic cigarette smoking raises the risk of lung cancer, the fact that only about $10 \%$ of chronic smokers develop lung cancer [31] suggests that a pathogenic stimulus is not sufficient unto itself to cause cancer, other pathways must be involved such that homeostasis is disrupted.

A pathogenic stimulus causes a reaction, an inflammation. The earliest report on the role of inflammation in carcinogenesis came in 1915 when coal tar derivatives, repeatedly applied to rabbit ears, induced skin cancer [32]. Since then, alkylating agents (sulfur mustard, ethylene dibromide, and many nitrosamines), arsenic, aflatoxins, asbestos, azo dyes, benzene, cigarette smoke, vinyl chloride, and radiation have all been associated with carcinogenesis $[18,19,23]$. A feature shared by these chemical carcinogens is an extended latency period between repeated exposures and the onset of cancer. A nonchemical example is the chronic inflammation in persistent achalasia associated with an estimated 140-fold increased risk of developing esophageal cancer [33].

The complex, yet insidious, nature of chronic inflammation can be seen both inside and outside the cell. Disruption of the glycocalyx, the thin layer of glycoproteins, and glycolipids that coats nearly every cell, can result in both altered signaling pathways and favor a proinflammatory state within the cell $[18,19]$.

One function of the glycocalyx is to protect cells and underlying tissues, while another serves as a direct mechanical-transducing link to couple the guanosine- $5^{\prime}$ triphosphate (GTP)-binding proteins of the cell membrane as well as promoting contact with microfilaments inside the cell $[18,34]$. The regeneration time after disruption of the glycocalyx is about $5-7$ days [35]. The consequences of the degradation of the glycocalyx involve increases in the number of intercellular adhesion molecule 1 (ICAM1, cluster of differentiation 54, CD54) on the cell surface, and activates the nuclear factor 
kappa-light-chain-enhancer of activated B-cells (NF-кB), thus fostering a pro-inflammatory state marked by elevated leukocyte adhesion [36]. The glycocalyx is found around epithelial, stromal, and tumor cells, and disruption by hyaluronidase and heparinase was reported to protect against flow-regulated invasion [37].

The role of adhesion molecules in carcinogenesis is being increasingly examined. The cytochrome $\mathrm{P} 450$ (CYP) metabolized statin, simvastatin, inhibits the adhesion of cancer cells to human mesothelial cells (HMCs) and decreases the adhesion molecules, vascular cell adhesion protein 1 (VCAM-1) on HMCs, and ICAM-1 and the cell surface receptor integrin beta 1 (integrin $\beta 1$, cluster of differentiation 29, CD29) chain expression in ovarian cancer cells. This opens up the possibility of a therapeutic role for simvastatin in patients with peritoneal carcinomatosis [38] perhaps by applying long-circulating liposomes as a constant delivery system for simvastatin [39].

The experiments by Zeng et al. revealed that blocking metalloproteinases (MMPs), the cell surface glycoprotein cluster of differentiation 44 (CD44), or integrin alpha 3 (integrin $\alpha 3$, cluster of differentiation $49 \mathrm{C}, \mathrm{CD} 49 \mathrm{C}$ ) decreases flow-induced migration. The authors theorized that sphingosine-1-phosphate (S1P), together with glycocalyx, Snail, and MMP signaling, mediate S1P-induced cell transition [40]. The protection of the glycocalyx is induced by S1P, thereby increasing its synthesis on endothelial cells mediated by the phosphatidylinositide 3-kinase (PI3K) pathway [41]. However, upon closer examination, it appears that S1P exerts different effects depending on where it acts within the organism [42, 43, reviewed in 44]. S1P plays a role in the chemotaxis of mast cells to sites of inflammation [45]. The disruption of the molecular homeostasis of sphingosine kinase isoforms (SphK) and S1P is thought to occur during carcinogenesis.

SphK is increased in breast cancer $[46,47]$ and is activated by cytokines, resulting in increases in intracellular S1P [48]. SphK-induced S1P accumulation suppresses apoptosis [49]. Overexpression of SphK facilitates cancer development [45,50]. S1P signaling in Epstein-Barr virus (EBV)-associated nasopharyngeal carcinoma activates protein kinase $\mathrm{B}$ (Akt, $\mathrm{PKB}$ ) and promotes cell migration through $\mathrm{S} 1 \mathrm{P}$ receptor 3 (S1PR3), while a knockdown of S1PR3 decreases Akt activation and the S1P-triggered migration of nasopharyngeal carcinoma cells in vitro [51].

In patients with inflammatory bowel disease (IBD), the risk of cancer is increased some 20-30-fold [52]. S1P is thought to be involved in the progression from IBD to cancer [53]. It may be that two homologous proteins (S1PL2021 and S1PL2025), which were recently reported in the pathogenic bacterium Burkholderia pseudomallei K96243, degrade host sphingolipids (SLs) via a mechanism mediated by the pyridoxal 5'-phosphate (PLP)dependent enzyme S1P lyase (S1PL) [54]. Exosomes secreted by enterobacteria trigger the intestinal epithelium to produce exosome-like nanoparticles derived from mucosa, which contain S1P, chemokine (C-C motif) ligand
20 (CCL20, macrophage inflammatory protein-3, MIP3A), and prostaglandin E2 (PGE2), which, in turn, promote Th17 cells and modulate intestinal inflammation [55].

Other indicators of disruption of cellular homeostasis include catenin delta-1 (protein 120, p120), conjugated bile acids (CBA), and PGE2. The cell adhesion protein 120 (p120, catenin delta-1) expression is elevated in chronic pancreatitis and can be diminished in tumors. It is thought that together with the signaling of extracellular S1P bound to S1P receptor 2 (S1PR2) on neighboring cells these changes could affect the progression to cancer [56]. Furthermore, CBA activate S1PR2 in hepatocytes [57] and, thereby, promote growth in cholangiocarcinoma through activation of S1PR2 [58].

CBA-induced cyclooxygenase 2 (Cox-2) expression in a human HuCCT1 CCA cell line is also associated with S1PR2-mediated upregulation of both Cox-2 expression and PGE2 production, highlighting the role of S1PR2 I bile acid-induced Cox-2 expression and abnormal cell growth [59]. The small molecule 3-(4-chlorophenyl)adamantane-1-carboxylic acid (pyridin-4-ylmethyl) amide (ABC294640) selectively inhibits sphingosine kinase 2 (SK2) activity leading to dose-dependent decreases in S1P expression [60]. It also targets sphingosine kinase isoforms, sphingosine kinase isoform 1 (SphK1) or sphingosine kinase isoform 2 (SphK2), inhibiting constitutive signal transduction and dose-dependent caspase cleavage, as well as apoptosis for Kaposi's sarcoma-associated herpes virus (KSHV)-positive patient-derived primary effusion lymphoma (PEL) cells [61].

\section{Pathogenic stimulus by virus}

Some 2,400 years ago, Hippocrates is believed to have coined the term "herpes" "to describe lesions that appeared to creep or crawl along the skin" although descriptive lesions seem to have been reported on a Summarian Tablet in the third Millenium BC and on the Ebers Papyrus about 1,500 BC [62-65]. Hippocrates (460-377 BC) first described the association of uterine cancer and inflammation [66, reviewed in 67] followed by Galen (approximately 130-210 AD) with "scleroma uteri est tumor subdurus in aliqua parte uteri oxortus qui plerumque ex diuturnis inflammationibus" [68, reviewed in 67]. Arataeus of Cappadocia (approximately first to third century AD) recognized the association of inflammation in liver cancer: "The liver inflammation persists, and the pus remain inside the liver, the pain persists too, the enlargement turns to a rough area and transformed to cancer" (reviewed in Ref. [67]).

John Abruc in 1736 investigated French prostitutes and linked herpes with genital lesions [69]. This was followed by Vidal, who in 1873 associated human herpes virus 1 (HSV-1, $H H V$-1) associated with oro-facial and human herpes virus $2(H S V$-2, $H H V$-2) with genital lesions including the suggestion that herpes may be infectious between humans [70], Steiner in 1875 linked human herpes virus 3( $H H V$-3, Varizella zoster virus, $V Z V)$ with chicken 
pox [71], and Unna 1883 associated human herpes virus $(H S V)$ with genital lesions but he described herpes as "...one of the most benign of afflictions both to the patient and her public" [72].

Kelsch and Kiener reported two cases of liver cancer in 1876 [73] and the first histological classification was done by Hanot and Gilbert [74]. Virchow differentiated between primary liver cancer and liver metastasis [75] followed by the subsequent distinctions between primary liver cancers derived from hepatocytes resulting in "hepatoma" (later hepatocellular carcinoma or HCC), and "cholangioma" deriving from the intrahepatic bile ducts (later cholangiocellular carcinoma or CCC) $[76,77]$.

The association of liver cancer and fibrosis was pointed out by Sabourin using the term hepatoma [78], and the association of hepatitis involved during liver cancer development was recognized in 1948 [79,80].

The association of hepatitis B virus (HBV) and liver cancer was made by Prince and Sherlock $[81,82]$ and the causal association was accepted [83] while the association of liver fluke and CCC was performed by Kartsurada 1900 and Hou 1955 [84,85, reviewed in 86].

The Irish surgeon, Denis Parsons Burkitt, then in Uganda, discovered that viruses were associated with cancer when he observed swellings in the angles of the jaw in children [87]. In 1961, Burkitt gave a lecture entitled "The Commonest Children's Cancer in Tropical Africa - A Hitherto Unrecognized Syndrome." In 1964, Michael Anthony Epstein, a pathologist, together with Bert Achong and Yvonne Barr, identified particles of virus in cells cultured from Burkitt's cancer patients [88], demonstrating that viruses were associated with what later became known as Burkitt's lymphoma. In 1968 and 1971, reports appeared that showed that cell-free extracts of human osteosarcomas inoculated in hamsters could induce the mesenchymal cancer, osteosarcoma $[89,90]$. Later, Balabanova et al. showed that the transformation of normal cells to cancer cells occurred in vitro after infection with two C-type viruses obtained from solid tumors [91,92]. In 1974, Epstein and Kaplan established the SU-DHL-1 lymphoma cell line from a 10-year-old boy suffering from diffuse histiocytic lymphoma [93]. Kaplan et al. later demonstrated in vitro that the $S U-D H L-1$ virus could infect human hematopoietic cells and transform them to malignant cells [94-96]. Subsequently, Gertrude and Werner Henle with collaborators from their Philadelphia laboratory developed serological markers and antibodies to the offending virus [97]. The first sero-epidemiological studies on $E B V$ were published in the late 1970s. [98]. Henle later showed that $E B V$ could affect a transition of normal lymphocytes to cancerous cells [99].

The association of $H S V$ with chronic inflammation [100-103] and the development of squamous dysplasia, carcinoma in situ, and cervical carcinoma has been proven since the 1860s [104-112]. Since 1981, a herpes classification is available [113]. The Hungarian dermatologist, Moritz Kaposi (1837-1902), reported an idiopathic skin sarcoma [114, reviewed in 115], which was essentially ignored until 1981 when human immunodeficiency virus (HIV) infection and acquired immune deficiency syndrome (AIDS) were associated with Kaposi sarcoma syndrome and opportunistic infections [116]. Human herpes virus 8 (HHV-8) causes PEL, multicentric Castleman disease (MCD), and Karposi sarcoma, a malignant cancer of blood vessels that is common in immune-compromised patients with AIDS [117].

Other viruses have also been causally linked to specific cancers and the association of chronic hepatitis $B$ or $C(H B V$ or $H C V)$ and liver cancer is established [118].

The associations of $H P V$ with cervical carcinoma [119], middle ear carcinoma [120], penile carcinomas [121,122], oropharyngeal cancer [123], tongue cancer [124], esophageal squamous cell carcinoma (ESCC) [125], colorectal cancer (CRC) [126,127], lung cancer [128-130], and breast cancer have since been demonstrated [131].

In regard to the herpes virus, another paradigm is falling. It was propagated for a long time that Alzheimer's disease was caused by mutations in the majority of cases [132-135], although we now know that only some $5 \%$ of Alzheimer's cases are causally linked to mutations [136]. Recently, it was pointed out that the majority of cases $(\geq 50 \%)$ seem to be caused by chronic inflammation induced by herpes virus species [137].

\section{Pathogenic stimulus by bacteria}

The association of Helicobacter pylori and gastric cancer [138] was long ignored [139]. Eventually, the pathogen was shown to cause fibrosis, one step in the proposed six-step sequence of carcinogenesis [18]. It is relevant that $>60 \%$ of infections by gastric spiral organisms (GSO) were observed in dogs and cats, where they act as a reservoir for subsequent human infection with H. pylori [140]. Dogs infected with this pathogen showed a greater incidence of moderate-to-severe gastritis than dogs that were H. pylori negative [141]. The mode of transmission of this gram-negative bacterium is unclear as is the possibility of transmission via fecal-oral, gastricoral, oral-oral, and sexual routes. H. pylori was shown to be present and to survive in food samples such as milk, vegetables, and meat, a fact that points to the role of environmental factors in assessing cancer risk [142].

H. pylori uses the serine protease, high temperature requirement $\mathrm{A}(\mathrm{Htr} \mathrm{A})$, to cleave important components of the tight junctions, such as occluding and claudin- 8 , and the cell-cell adhesion protein cadherin-1 (E-cadherin), making transcellular migration possible [143]. Bacterial adaptations to the cellular milieu are Type IV secretion systems (T4SSs) found in gram-negative and grampositive bacteria [144]. In H. pylori infection, T4SSs is formed at the basolateral epithelial membrane. After disrupting cell-cell junctions and binding to the integrin$\beta 1$ receptor, the cytotoxin-associated gene A (CagA) protein of $H$. pylori is injected into the host [143]. It has recently been shown that CagA deregulates autophagy and promotes chronic inflammation through 
tyrosine-protein kinase Met (c-Met, hepatocyte growth factor receptor, HGFR)-PI3K/Akt- mechanistic target of rapamycin (mTOR) signaling [145].

\section{Disruption of gut bacteria composition as internal pathogenic stimuli}

The roles of bacteria as pathogenic stimuli were examined in a population-based study in postmenopausal women by comparing 48 breast cancer cases with 48 contemporaneous age-matched controls [146]. Adjustment for estrogens and other variables showed "...reduced alpha diversity and altered composition of both their IgA-positive- and IgA-negative faecal microbiota," revealing that "breast cancer cases had significant oestrogenindependent associations with the IgA-positive and IgA-negative gut microbiota." An investigation of 668 breast tumor tissue and 72 noncancerous adjacent tissue was performed to try to characterize microbiota and to study associations of microbiota with tumor expression profiles [147]. To confirm the presence of microbiota, sequencing of the $16 \mathrm{~S}$ rRNA gene was used to identify unknown bacteria "or for providing reference identifications for unusual strains" [148]. Thompson et al. found that Escherichia coli was "one of the more prevalent species in the breast tissue and is observed in higher abundance within non-cancer breast tissues." Furthermore, a greater shift in the abundance of Proteobacteria in cancer tissues was observed compared to Actinobacteria in noncancer tissues. Listeria spp. was associated with expression profiles of genes involved with cell transition and $H$. influenza was associated with proliferative pathways, such as G2M checkpoint, E2F transcription factors, and mitotic spindle assembly [147].

A nested case-control study of two prospective cohort studies, the American Cancer Society Cancer Prevention Study II Nutrition Cohort (CPS-II) and the Prostate, Lung, Colorectal, and Ovarian Cancer Screening Trial (PLCO), investigated head and neck squamous cell cancer (HNSCC) and identified 129 incident cases of HNSCC that provided oral mouthwash samples, and that were cancerfree at baseline through bacterial $16 \mathrm{~S}$ rRNA gene sequencing (oral microbiome composition and bacterial abundances) [149]. Although the statistical power was low, greater abundances of Corynebacterium and Kingella were associated with decreased HNSCC risk. Additionally, there was a tendency for stronger associations with laryngeal cancer and for patients with a tobacco history. Blastocystis sp. was isolated from fecal samples and inoculated into rats treated with the carcinogen, azoxymethane (AOM), Blastocystis sp. co-treatment, and a control group [150]. Histologically, AOM-treated rats with co-administration of Blastocystis sp. cyst resulted in a 1.6 -fold increase in the number of crypts compared to AOM-treated rats. Foci of aberrant crypts were observed in AOM-controls and Blastocystis sp. infected AOM-rats. Tubular adenomas with very mild dysplasia were observed in AOM-treated rats compared to major dysplasia with hyperplastic aberrant crypts rats treated with AOM and
Blastocystis sp. Furthermore, the authors found higher oxidative stress parameters (lipid peroxidation, protein damage) in Blastocystis sp. infected AOM-rats compared to the AOM-treated controls. Higher levels of advanced oxidative protein products (AOPP) were also found in the serum [150], which is concordant with high plasma AOPP levels found in CRC patients compared to healthy individuals [151].

Methylobacterium radiotolerans was observed to be enriched in breast cancer tissue compared to an abundance of bacterium Sphingomonas yanoikuyae in paired normal tissue [152]. This inverse microbial dysbiosis was concordant to an investigation of both bacteria in sentinel lymph node specimens from breast cancer patients [153]. However, it is not clear how these data explain the observation of 2266 women treated with antibiotics who were found to be at higher risk [2.07 (95\% CI $=1.48-2.88)]$ of developing breast cancer [154].

The role of bacteria as pathogenic stimuli was examined in tissue samples from 57 breast cancer patients and compared to that in breast tissue samples taken from 21 healthy women undergoing cosmetic breast surgery. Bacterial 16S rRNA is amplified from oral, urine rinse and breast tissue collected by surgery, sequenced, and processed. Methylobacterium was found primarily in noncancer patients. Urinary gram-positive bacteria such as corynebacterium, staphylococcus, actinomyces, and Propionibacteriaceae were increased in cancer patients independent of menstrual status. The authors suggested that there was a different local breast cancer microbiome between cancer and noncancer patients [155]. Sequencing of the $16 \mathrm{~S}$ rRNA gene was used to detect previously unidentified bacteria "or for providing reference identifications for unusual strains" [148]. Wang et al. found that compared to controls, clustered microbiomes in breast cancer tissue, "...driven by a decreased relative abundance of Methylobacterium in cancer patients" [155]. Plantassociated methylobacteria were previously thought to act as coevolved phytosymbionts [156] and methylobacterium rarely causes infections [157], while phytohormones are considered to be protective against cancer, making this observation interesting $[158,159]$.

In another investigation of mucosal tissues from 150 patients who underwent colonoscopy, the authors reported a high degree of concordance between colonization with enterotoxigenic Bacteroides fragilis (ETBF) and low-grade dysplasia (LGD), tubular adenomas (TA), and serrated polyps, and thus with precancerous lesions [160]. Additional evidence for internal pathogenic stimuli comes from the fact that bacterial aggregates are associated with proximal colon cancers [161]. Fusobacterium and Providencia were shown to be associated with the cancer microenvironment [162].

Although dermatophytes usually cause superficial fungal infections of the skin in immunocompromised patients, Trichophyton rubrum can cause deep dermatophytosis with hematogenous dissemination [163]. It has been suggested that dermatophytes could trigger mycosis fungoides [164]. Zhang et al. reported that about $25 \%$ of 
20 medulloblastomas contained the deoxyribonucleic acid (DNA) of Brucella species by the OMP31 primer/probe set; none of the medulloblastomas had a specific sequence for B. mellitensis, B. suis, or B. abortus [165]. Fusobacterium nucleatum ssp. animalis induced chronic inflammation and monocyte/macrophage activation, which could promote cancer development [166].

Chronic inflammation has been shown to initiate pancreatic carcinogenesis without a K-ras mutation and in the absence of a tumor protein 53 (p53) mutation [167].

\section{Pathogenic stimulus by fluke}

CCC has been associated with liver fluke (Opisthorchis viverrini) [168-170]. Thailand has the highest CCC rates worldwide, especially in the northern and northeastern part [171]. This is concordant with the finding that the "...majority of the infected cases $(64.3 \%)$ were found from the immigrants of northeastern Thailand (the fluke-prevalent region), providing 2.28-2.42 times higher infectious risk on average against the local residents." The prevalence of O. viverrini, Schistosoma mekongi, and soil-transmitted helminths (STH) is also high in the Lao People's Democratic Republic (Lao PDR), and animal infections rates, as well as water, might serve as a reservoir for humans [172]: "O. viverrini and $S$. mekongi infection rates among dogs and cats were $25.0 \%$ and $14.7 \%$, respectively. Of the cats tested, $53.1 \%$ were infected with $O$. viverrini. Prevalence of $O$. viverrini and S. mekongi in snails was $0.3 \%$ and $0.01 \%$, respectively. Overall prevalence of $O$. viverrini infection in fresh water fish was $26.9 \%$, with the highest infection rates occurring in Hampala dispa (87.1\%)."

According to the six-step carcinogenesis sequence [18], $O$. viverrini infection is associated with a two to three times increase of plasma inflammatory indicators, 8-isoprostane, malondialdehyde, and nitrate/nitrite, while plasma C-reactive protein (CRP) levels did not differ compared to healthy controls [173]. In a rodent model, inflammation with severe periductal fibrosis and changes in the epithelium of the biliary tract, as precancerous lesions, were induced by the liver fluke Opisthorchis felineus [174]. Furthermore, the combination of $O$. viverrini infection and chemical carcinogen induced $\mathrm{CCC}$ in hamsters through inflammatory mechanisms with an increase of cluster of differentiation 4 positive $(\mathrm{CD} 4+$ ) and interleukin 17 positive (IL-17+) cells, and intense staining of the transcription factor Forkhead-Box-Protein P3 (FoxP3) was reported and was consistent with their protein levels [175]. Applying $N$-acetyl-5-methoxy tryptamine (melatonin) suppressed IL-17+ inflammatory cells and Foxp3 + cells and increased CD4 + cell infiltration and tumor necrosis factor alpha $(\mathrm{TNF} \alpha)$ expression.

IL-17 is a pleiotropic cytokine involved in carcinogenesis $[176,177]$ and possess antitumor effects through a T-cell dependent mechanism [178]. IL-17 reveals heterogeneous immunohistochemistry (IHC) expression in CRC compared to normal tissues [179]. IL-17 is increased in breast cancer, where it enhances TNF $\alpha$-indeced increase in hypoxia-inducible factor $(\mathrm{HIF}-1 \alpha)$ with inhibition of vasodilator-stimulated phosphoprotein (VASP) and consequent reduction of adhesion [180]. Activating STAT3 by IL-17 decreases myeloid-derived suppressor cells (MDSCs) in breast cancer [181]. IL-17 stimulates interleukin 6 (IL-6) expression 13-fold and interleukin 8 (IL-8) 28 -fold in benign prostate hyperplasia (BPH) cells but in situ measurements showed that the amount of $17 \mathrm{mRA}$ in BPH cells did not correlate with IL-6 or IL- 8 mRNA but rather was strongly correlated in prostate cancer tissues [182]. Furthermore, IL-17 increases in vivo tumor growth in human nonsmall cell lung cancer (NSCLC) in SCID mice through CXCR-2-dependent angiogenesis [183]. MMP-9, MMP-2 via NF-кB/hypoxia-inducible factor (HIF-1 $\alpha$ ) pathway is increased by IL-17 in rheumatoid arthritis, promoting cell migration [184], and MMP-9 through mitogen-activated protein kinase 3 (ERK1) and mitogen-activated protein kinase 1 (ERK2) MAPK activation [185].

The IL-1/IL17 signaling axis contributes in inflammatory remodeling of fibrosis in systemic sclerosis [186]. IL-17 increase via IL-6, TNF, CCL20, and C-X-C motif ligand 1 (CXCL1) in heart failure with consecutive enhancing tissue remodeling [187]. The activation of the IL-17/ long noncoding RNA-AK081284 (AK081284)/TGFß1 increases cardiac interstitial fibrosis, while Il-17 knockout results in decrease of remodeled fibrosis and improved cardiac function in mice [188]. There are also contradictory findings, namely, pulmonary fibrosis is increased via IL-17 induced Th17 cells [189], while renal interstitial fibrosis can be inhibited by IL-17 [190], which may be dependent on the IL-17 concentration as low dose IL-17 can prevent diabetic nephropathy [191]. It is known that the effect of IL-17 in allergic airway inflammation depends on the quantity as well as the cellular source of IL-17 [192], and using anti-IL-17 in psoriasis resulted in "dose-dependent reductions from baseline in keratinocyte proliferation, hyperplasia, epidermal thickness, infiltration into the dermis and epidermis by T cells and dendritic cells" [193].

IL-17 seems to have dose- and cell source-dependent inflammatory and pro-fibrotic effect, whereas interleukin 22 (IL-22) was associated with protecting against liver fibrosis through downregulation of the TGF- $\beta 1 /$ Notch signaling pathway [194] but being pro-fibrotic in cardiac fibrosis through STAT3/and ERK and IL-17, IL-6, IL-1 $\beta$, IFN- $\gamma$, and TNF- $\alpha$ [195] and pro-atherosclerotic [196]. Both, IL-17 and IL-22 are associated with poor prognosis in liver cancer [197], but the exact roles of IL-17 and IL-22 need to be defined in detail in regard to concentration, kind of inflammation, and period of chronic inflammation involved in signaling axis and cell sources.

New interactions between chronic inflammation contain aquaporines (AQPs) and autophagy, both getting increasingly into cancer research focus [198-200].

\section{Aquaporines (APQ)}

The aquaporines (AQPs) are a family of small hydrophobic membrane proteins in the animal and plant kingdom that are involved in transport of water and in 
water homeostasis, which was first reported in 1992 by Peter Agre's group [201] and for which he received the Nobel Prize in Chemistry in 2003. AQPs are involved in concentrating the urine within the kidneys and the salivary glands as well as within the liver for glycogenesis [202-205].

AQPs are expressed "in many epithelia and endothelia involved in fluid transport, as well as in cell types that are thought not to carry out fluid transport, such as skin, fat and urinary bladder cells" [206]. The various AQP function roles include trans-epithelial fluid transport, tissue swelling, cell migration, fat metabolism, pathophysiology of obesity, immune cell dysfunction, cancer, and other diseases. Piscine aquaporins, in Agnatha (jawless fish), Chondrichthyes (chimaeras, sharks, and rays), Dipnoi (lungfishes), and Teleostei (ray-finned bony fishes) "imply the physiological roles of piscine aquaporins extend at least to osmoregulation, reproduction, and early development" [207]. Research revealed the association of various AQPs with cancer, its development, and metastasis [208-214]. However, AQP seem to be heterogeneously expressed in highly aggressive cancers with increased cell migration and cell proliferation [215].

Papadopoulos et al. proposed a mechanism how AQPs may play a role in a kind of amoeboid cell migration important for metastasis and by which rapid changes in cell volume facilitated by AQP include [216] actin depolymerization and ionic influx with increased osmolality at the front end of the cell, water influx followed by actin re-polymerization with formation of localized cell membrane protrusions. There is hope that AQP inhibitors or modulators might serve as future drugs for slowing down tumor growth and migration [216,217].

The fluid clearance within the pancreatic duct chronic pancreatitis is in addition dependent on AQPs and not just on outflow obstruction: aquaporin 1 (AQP1) is mainly localized at the apical membrane of ductal cells in the human pancreas and AQP1 expression in mice is dependent on the cystic fibrosis transmembrane conductance regulator protein and chlorid channel $\left(\mathrm{CFTR} \mathrm{Cl}^{-}\right)$, channels in mice. Induction of acute pancreatitis by intraperitoneal injection of cerulean in mice resulted in decreased channel expression, which was concordant to findings in human with acute and chronic pancreatitis [218]. AQP1 knockdown worsened the pancreatitis with significant decrease of pancreatic ductal fluid and hydrogencarbonat $\left(\mathrm{HCO}_{3}{ }^{-}\right)$secretion with increased chronic inflammation.

A disruption of AQPs in chronic inflammation and various diseases was observed: upregulation of aquaporin 1 (AQP1) in rheumatoid arthritis [219] versus a downregulation of aquaporin $4(\mathrm{AQP} 4)$ and 8 (AQP8) in colitisinduced mice [220], and increased AQP1, aquaporin 3 (AQP3), aquaporin 7 (AQP7), and aquaporin 8 (AQP8) in early untreated human IBD [221]. The anti-inflammatory mediator, lipoxin A4 (LXA4, 5S,6R,15S-trihydroxy$7 \mathrm{E}, 9 \mathrm{E}, 11 \mathrm{Z}, 13 \mathrm{E}$-eicosatetraenoic acid) [222], regulates aquaporin 5 (AQP5) and metalloproteinase 9 (MMP-9, gelatinase B) in pancreatitis-associated lung injury through the protein kinase $\mathrm{C}(\mathrm{PKC}) /$ src-suppressed C-kinase substrate (SSeCKS) pathway with F-actin reconstruction [223].

AQP1 is thought to be involved in the differentiation of gastric cancer cells [224], and AQP3 and aquaporine 9 (AQP9) can be induced by arsenite with inhibition of apoptosis via decreasing p53 and increasing B-cell lymphoma 2 (Bcl-2) [225]. AQP1 and AQP5 are increasingly expressed at the apical membrane of intercalated pancreatic duct cells [226], and increased AQP5 levels result into "retinoblastoma protein phosphorylation through the formation of a nuclear complex with cyclin D1 and CDK4" [227]. AQP3 was found to be increased in advanced stages of pancreatic cancer, and AQP5 is more closely associated with tumor differentiation [228].

\section{Autophagy}

The mechanism a cell uses to rid itself of unnecessary or dysfunctional components is termed autophagy [229]. It was coined by Christian de Duve in 1963 [230, reviewed in 229]. Intracellular bacterial infections [231] such as propionibacterium acne [232], Shigella and Salmonella [233], H. pylori [234], and viruses [235] can generate autophagy. The accumulation of intracellular amino acids induces a dissociation of mTOR from the membrane with downregulation of its activity. At the same time, the amino acids activate EIF2AK4/GCN2-EIF2S1/eIF2 $\alpha$ / ATF-3 signaling (eukaryotic translation initiation factor 2-alpha kinase $4\left(\mathrm{EIF}_{2} \mathrm{AK}_{4}\right)$ /general control nonderepressible 2 (Gcn2)-eukaryotic translation initiation factor 2 subunit 1 (eIF2 $\alpha$, EIF2S1)/eukaryotic translation initiation factor 2 subunit 1 (eIF $2 \alpha)$ /cyclic AMP-dependent transcription factor (ATF-3)) [233].

It has recently been reported that endogenous nuclear fragments, such as chromatin, evoke a chronic inflammatory response within the cytoplasm also leading to autophagy [236]. An external pathogenic stimulus also induces an internal protection shield process for the cell, termed consecutive autophagy [237].

Autophagy is linked to subclinical inflammation especially in precancerous lesions such as inflammatory bowel diseases (IBD), in which autophagy controls colitis by decreasing TNF-induced apoptosis [238], which is why autophagy in IBD is seen as a protection against cell suicide for the gut epithelium [239]. But the contradictory findings have not been fully explained. Chronic pancreatitis is associated with progressive chronic inflammation and a precancerous condition for pancreatic cancer [240,241].

Long noncoding RNA metastasis-associated lung adenocarcinoma transcript 1 (MALAT1) is increased in pancreatic cancer and is associated with poor survival [242,243] and promotes cancer progression by autophagy activation [244]. Retinoblastoma-coiled coil protein 1 (RB1CC1) mediates autophagy, which is seen as a key event for the activation of pancreatic stellate cells (PSCs), and knocking down retinoblastoma-coiled coil protein 1 
(RB1CC1) expression alleviates autophagy, which suggests an opportunity of a potential use as a therapeutic approach in chronic pancreatitis and fibrosis [245].

On the one hand, site lipopolysaccharide (LPS)induced autophagy is associated to promote autophagy in gingival fibroblasts [246], while Mycobacterium leprae can inhibit autophagy [247]. Autophagy may be even a protection strategy of cancer cells against multimodal therapy-induced apoptosis [248]. As pointed out, there are gaps in our knowledge in regard to dysregulation of autophagy [249].

\section{Chronic inflammation}

The interactions between mast cells, T-cells, neutrophils, granulocytes, and macrophages are complex such that the chronic activation of one or more of these results in the release of pro-inflammatory cytokines (examples included in Fig. 1) and those, in turn, are linked to the development of fibrosis [250-253]. The chronic activation of macrophages brings about a chronic release of $\mathrm{TNF} \alpha$, interleukin beta 1 (IL- $\beta 1)$, and oncostatin-M (OSM) and leads to a continuous activation of fibroblasts [254-256].

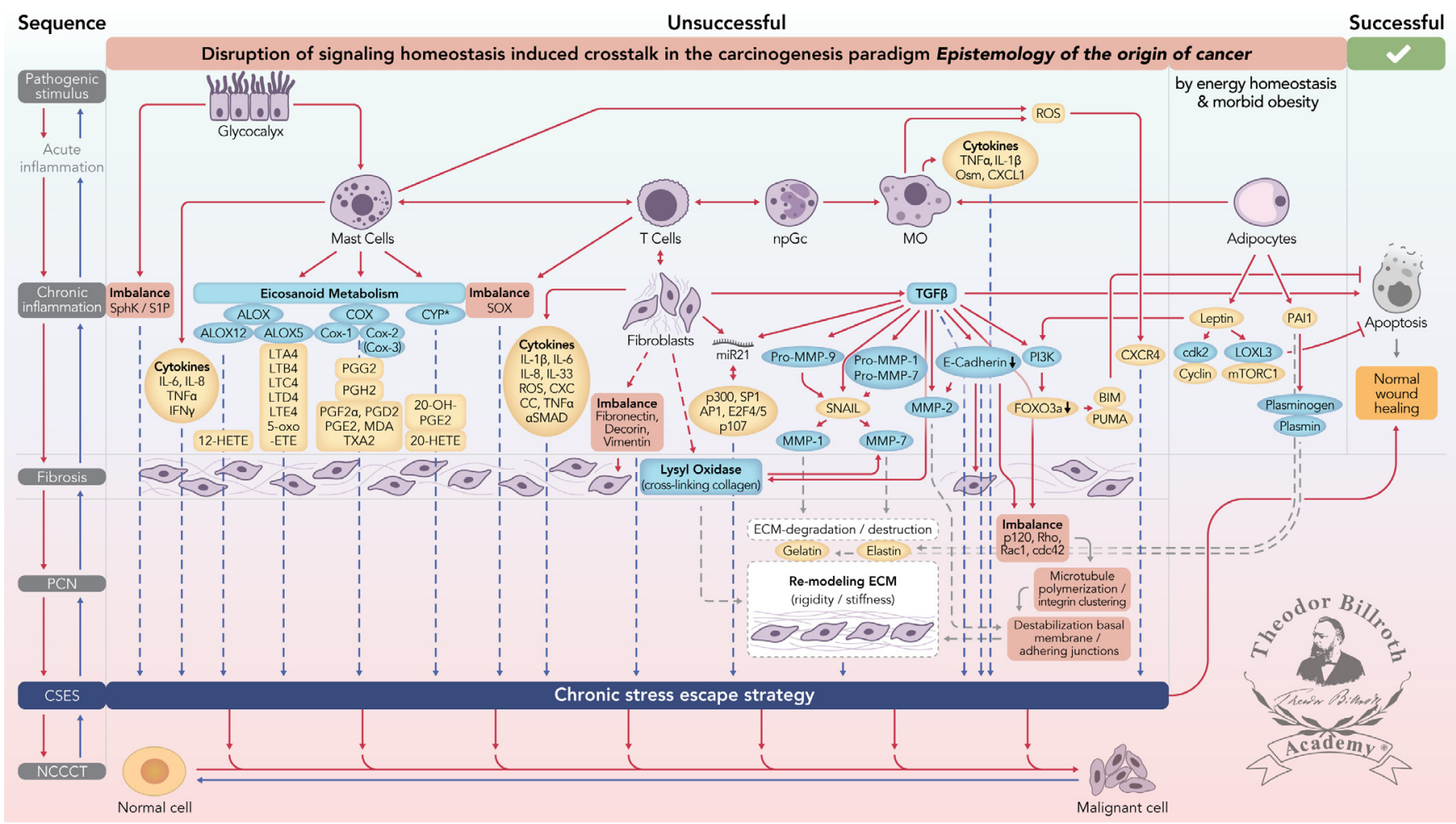

Fig. 1. Simplified scheme of the disruption of signaling homeostasis-induced crosstalk in the carcinogenesis paradigm "epistemology of the origin of cancer" consisting of a six-step sequence: (1) a pathogenic stimulus followed by (2) chronic inflammation from which develops (3) fibrosis with associated remodeling of the cellular microenvironment; and from these changes a (4) precancerous niche (PCN), a product of fibrosis, with remodeling by persistent inflammation, develops that triggers the deployment of (5) a chronic stress escape strategy and when this fails resolve it by (6) normal cell to cancerous cell transition (NCCCT) by PCN-induced cell matrix stress occurs. This figure was published as original illustration in paper 3 of this Special Issue - Disruption of homeostasis-induced signaling and crosstalk in the carcinogenesis paradigm "Epistemology of the origin of cancer" entitled "Chronic inflammation evoked by pathogenic stimulus during carcinogenesis". We point out, that to the complexity of the content of the Special Issue the original and/or modified version of the original illustration was republished within the following papers of the Special Issue: paper 5 "Microbiome and morbid obesity increase pathogenic stimulus diversity", paper 6 "Precancerous niche (PCN), a product of fibrosis with remodeling by incessant chronic inflammation", paper 7 "Metformin alters signaling homeostasis", paper 8 "Transition from normal to cancerous cell by precancerous niche (PCN) induced chronic cell-matrix stress" and paper 9 "NF- $\mathrm{B}$ signaling and crosstalk during carcinogenesis". Nomenclature: The nomenclature common abbreviations are in bold, followed by the common trivial names (if available) and (if available) by the name in accordance to the International Union of Pure and Applied Chemistry (IUPAC): PCN precancerous niche; CSES chronic stress escape strategy; NCCCT normal cell to cancerous cell transition; SphK sphingosine kinase isoform; S1P sphingosine-1-phosphate; IL-6 interleukin 6; IL-8 interleukin 8; TNF $\boldsymbol{\alpha}$ tumor necrosis factor alpha; IFN $\boldsymbol{\gamma}$ interferon gamma; ALOX lipoxygenase, arachidonate lipoxygenase; ALOX12 12-lipoxygenase, 12-LOX, 12S-LOX, arachidonate 12-lipoxygenase 12S type; ALOX5 5-lipoxygenase, 5-LOX, arachidonate 5-lipoxygenase; 12-HETE 12-hydroxyeicosatetraenoic acid; LTA4 leukotriene A4, 4-[(2S,3S)-3-[(1E,3E,5Z,8Z)-tetradeca-1,3,5,8-tetraenyl]oxiran-2-yl]butanoic acid; LTB4 leukotriene B4, (5S,6Z, $8 E, 10 E, 12 R, 14 Z)$-5,12-dihydroxyicosa-6,8,10,14-tetraenoic acid; LTC4 leukotriene C4, $(5 S, 6 R, 7 E, 9 E, 11 Z, 14 Z)-6$-[(2R)-2-[[(4S)-4amino-4-carboxybutanoyl]aminol-3-(carboxymethylamino)-3-oxopropyl]sulfanyl-5-hydroxyicosa-7,9,11,14-tetraenoic acid; LTD4 leukotriene D4, (5S,6R,7E,9E,11Z,14Z)-6-[(2R)-2-amino-3-(carboxymethylamino)-3-oxopropyl]sulfanyl-5-hydroxyicosa-7,9,11,14tetraenoic acid; LTE4 leukotriene E4, (5S,6R,7E,9E,11Z,14Z)-6-[(2R)-2-amino-2-carboxyethyl]sulfanyl-5-hydroxyicosa-7,9,11, 
Chronic activation of mast cells also produces a release of cytokines as well as activating T-cells and fibroblasts [257] (Fig. 1). T-cells, involving a ligand such as cluster of differentiation 40 (CD40) in antigen presenting cells, mediate the contact activation of endothelial cells [258]. Such a process is one plausible mechanism to generate the observed chronic inflammation. Post-partum-activated fibroblasts were associated with increased Ly6C + monocytes, decreased CD8 $+\mathrm{T}$ cells, and apoptosis. They displayed pro-tumorigenic, immunosuppressive activity through Cox-2/PGE2-dependent pathways [259]. This phenomenon is also a reason to consider immunosuppression in cancer therapy.

The immunosuppressive enzyme, indoleamine-2,3dioxygenase (IDO), is produced in all tissue types [260]. Mice cells transfected with IDO become resistant to immunologic rejection [261], and IDO expression is associated with various cancers such as pancreatic [262,263], gastric [264,265], colorectal [266], breast [267], ovarian, and endometrial [268,269]. The expression of IDO isoforms differs among the various cells; tryptophan degradation by IDO is effected entirely by IDO1 but not IDO2 [264]. Applications of the heme precursor compound, zinc protoporphyrin IX (ZnPP), in a preclinical melanoma model, effectively inhibited IDO [270].

Chronic fibroblast activation alone can lead to a vicious cycle as seen in liver cirrhosis, the end stage of chronic hepatitis. It is a tissue with an abnormal reconstruction of the lobular architecture that contains parenchymal nodules and septa that link the portal with central canals [271]. Popper described the vicious cycle in the creation of hepatocellular fibrosis: "...hepatocellular injury and the associated inflammation produce pericellular fibrosis interfering with cellular nutrition and septa-disturbing hemodynamics. This, in turn, induces additional liver cell injury."
The negative regulator of Wnt signaling [272], the tumor-suppressor gene, adenomatous polyposis coli (APC), exhibits multiple functions. Silenced APC by promoter methylation was greater in HCC tissue than in noncancerous tissue and the level of APC protein expression was reduced in HCC [273]. The APC tumor suppressor gene also downregulates intestinal transport mediated by both electrogenic sodium-glucose transport protein 1 (SGLT1) and by the $\mathrm{Na}^{+} / \mathrm{H}^{+}$exchanger (NHE3) [274]. It increases the nuclear factor of activated $\mathrm{T}$ cells (NFAT) in a microtubule-dependent fashion. APC deficiency in mice reduced NFAT within the nucleus of intestinal regulatory $\mathrm{T}$ cells (Tregs), leaving a disturbed Treg differentiation together with anti-inflammatory cytokine, interleukin 10 (IL-10) [275]. APC migration in prostate cancer cells is induced by transforming growth factor beta 1 (TGF- $\beta 1$ ) and regulated by Smad7 and p38 mitogen-activated protein kinase (p38 MAPK) [276]. The interaction with microtubules plays an important role in this process.

Aspirin has been demonstrated to inhibit nuclear factor kappa-light-chain-enhancer of activated B cells (NF-кB) signaling and increase APC expression. Furthermore, it is associated with decreased polyposis in mice as well as in familial adenomatous polyposis (FAP) patients, and decreases the risk of developing CRC [277, reviewed in 278].

For the past 25 years, APC was thought to serve as one of the models for the origin of CRC as the APC mutation is also associated with both familial adenomatous polyposis (FAP) [279] and CRC [280]. However, APC mutations are not seen in mice models that were attributed to the limited lifespan of mice [281]. However, a few years ago it was shown that APC mutations occur at a late stage of tumor formation [282]. From this, and the observation that in a recent mouse model with a germline APC mutation,

14-tetraenoic acid; 5-oxo-ETE (6E,8Z,11Z,14Z)-5-oxoicosa-6,8,11,14-tetraenoic acid; Cox cyclooxygenase; Cox-1 cyclooxygenase 1; Cox-2 cyclooxygenase 2; Cox-3 isoform of Cox-2 (therefore in brakes); PGG2 prostaglandin G2, (Z)-7-[(1S,4R,5R, $6 R)$-5-[(E,3S)-3-hydroperoxyoct-1-enyl]-2,3-dioxabicyclo[2.2.1]heptan-6-yl|hept-5-enoic acid; PGH2 prostaglandin H2, (Z)-7$[(1 S, 4 R, 5 R, 6 R)-5$-[(E,3S)-3-hydroxyoct-1-enyl]-2,3-dioxabicyclo[2.2.1]heptan-6-yl]hept-5-enoic acid; PGFF2 $\boldsymbol{\alpha}$ prostaglandine F2 alpha, $(Z)$-7-[(1R,2R,3R,5S)-3,5-dihydroxy-2-[(E,3S)-3-hydroxyoct-1-enyl]cyclopentyl]hept-5-enoic acid; PGD2 prostaglandin D2, (Z)-7-[(1R,2R,5S)-5-hydroxy-2-[(E,3S)-3-hydroxyoct-1-enyl]-3-oxocyclopentyl]hept-5-enoic acid; PGE2 prostaglandin E2, $(Z)$-7[(1R,2R,3R)-3-hydroxy-2-[(E,3S)-3-hydroxyoct-1-enyl]-5-oxocyclopentyl]hept-5-enoic acid; MDA malondialdehyde, propanedial; TXA2 thromboxane A2, $(Z)$-7-[(1S,2S,3R,5S)-3-[(E,3S)-3-hydroxyoct-1-enyl]-4,6-dioxabicyclo[3.1.1]heptan-2-yl]hept-5-enoic acid; CYP* cytochrome P450 isoforms; 20-OH-PGE2 20-hydroxy prostaglandin E2; 20-HETE 20-hydroxyeicosatetraenoic acid, $(5 Z, 8 Z, 11 Z, 14 Z)$-20-hydroxyicosa-5,8,11,14-tetraenoic acid; SOX [sex-determining region Y (Sry) box-containing] transcription factor family; IL- $\boldsymbol{\beta} 1$ interleukin beta 1; IL-33 interleukin 33; ROS reactive oxygen species; CXC CC chemokine receptors; $\boldsymbol{\alpha}$ SMAD alpha-smooth muscle actin; miR21 micro RNA-21; p300 protein 300 (p300-CBP coactivator family); SP1 specificity protein 1; AP1 activator protein 1; E2F4/5 cytoplasmic complex of Smad3, retinoblastoma-like protein 1 (P107, RBL1), E2F4/5 and d-prostanoid (DP1); p107 retinoblastoma-like protein 1, RBL1; TGF $\boldsymbol{\beta}$ transforming growth factor beta; Pro-MMP-9 pro-matrix metalloproteinase 9; Pro-MMP-1 pro-matrix metalloproteinase 1; Pro-MMP-7 pro-matrix metalloproteinase 7; SNAIL zinc finger protein SNAI1; MMP-1 matrix metalloproteinase 1; MMP-7 matrix metalloproteinase 7; MMP-2 matrix metalloproteinase 2; E-Cadherin CAM 120/80 or epithelial cadherin, cadherin-1, epithelial cadherin; CXCL1 chemokine (C-X-C motif) ligand 1; Osm oncostatin-M; PI3K phosphatidylinositide 3-kinase; FOXO3a forkhead box protein O3a; p120 catenin delta-1, protein 120; Rho Ras homolog gene family, member A; Rac1 Ras-related C3 botulinum toxin substrate 1; cdc42 cell division control protein 42 homolog; BIM Bcl-2 interacting mediator of cell death; PUMA BH3-only protein; CXCR4 C-X-C motif of chemokine receptor 4; cdk2 cyclin-dependent kinase 2; LOXL3 lysyl oxidase homolog 3; mTORc1 rapamycin complex 1; PAI1 plasminogen activator inhibitor-1. 
ApcmNLS/mNLS mice rarely developed tumors [283], the hysteron proteron syllogism should be noted "...because the first event (mutations), in fact occur later in the process, i.e., only after the cell has been transformed from a normal cell to a cancer cell via a process termed carcinogenesis" [23].

Nuclear APC protects against colitis-associated colon tumorigenesis by suppressing inflammation, inhibiting Wnt signaling, and increasing colonocyte differentiation and mucus production [284]. Promoter methylation and APC silencing (reviewed in Refs. [285,286]) were observed in about $70 \%$ of inflammatory breast cancers [287], as well as in some $90 \%$ of lung cancers [288,289] (and prostate cancers [290-292]). This rate was equaled in both sporadic and familial breast cancer [293], again questioning the role of mutations as being causal to the majority of cancers.

Epithelial cancer cells use IL- $\beta 1$ as a communication factor to instruct stromal fibroblasts, through p53, to generate a pro-tumorigenic inflammatory microenvironment. This process is mediated (without any mutations) through $\mathrm{p} 53 / \mathrm{NF}-\mathrm{\kappa B}$ and results in chronic inflammation and fibroblast activation in ovarian cancer [294]. Anti-inflammatory therapy with Ustekinumab, a p40 subunit inhibitor of interleukin 12 (IL-12) and interleukin 23 (IL-23), in patients suffering from Crohn's disease, who were intolerant to TNF antagonist therapy, yielded positive laboratory and endoscopic responses [295]. Both findings suggest that yet chronic inflammation is an early and obligatory event in the genesis of cancer.

The activation and interaction of $\mathrm{T}$ cells with neutrophils and the associated cytokine release result in a continuous activation of macrophages, which, in turn, release metalloproteinase 3 (MMP-3, stromelysin-1). MMP-3 activates Pro-MMP1 and Pro-MMP-7 [296,297] (Fig. 1). Metalloproteinase 1 (MMP-1, interstitial collagenase) results in degradation of the extracellular matrix (ECM) with an increase of gelatin, metalloproteinase 7 (MMP-7), and elastin [298-301]. Furthermore, Snail and Smad interacting protein 1 (SIP1) are associated with an upregulation of the MMP family - MMP-1, metalloproteinase 2 (MMP-2, gelatinase A), MMP-7, and metalloproteinase 14 (MMP-14) - together with a downregulation of E-Cadherin [302,303]. The resultant effect increases remodeling of the microenvironment favoring the development of the precancerous niche $(\mathrm{PCN})$ while also downregulating apoptosis.

\section{Summary}

Unresolved chronic inflammation is an early and necessary phenomenon in the six-step carcinogenesis paradigm. The signaling and crosstalk pathways that go awry during chronic inflammation are complex because they occur both inside and outside the cell and include various cell types, proteins, and proinflammatory cytokines $[139,222,304]$. Even intracellular nuclear fragments, such as chromatin, trigger chronic inflammation and affect autophagy. One end product of persistent inflammation is fibrosis, which is a preliminary stage before the formation of the PCN [139]. Various pathogenic stimuli associated with different neoplasms result in persistent inflammatory micromilieu inducing an ongoing dysregulation of homeostasis at the cell, tissue, and organ levels. This disruption of homeostasis is an obligatory early step in carcinogenesis. Similar to other steps in carcinogenesis, a mutation is not necessary to explain carcinogenesis. The interplay of various cells, such as mast cells, macrophages, monocytes, $\mathrm{T}$ cells, and fibroblasts with diverse cytokines reveals considerable complexity. The "Disruption of signaling homeostasis induced crosstalk in the carcinogenesis paradigm Epistemology of the origin of cancer" (Fig. 1) becomes more complex by the involvement of the microbiome and obesity [305] and various hydrophobic hormone-like substances, built out of polyunsaturated fatty acids: the eicosanoids [222].

\section{Nomenclature of abbreviations (used in the text and the figure)}

\author{
5-oxo-ETE $\quad(6 E, 8 Z, 11 Z, 14 Z)-5$-oxoicosa-6,8,11,14- \\ tetraenoic acid \\ 12-HETE 12-hydroxyeicosatetraenoic acid \\ 20-OH-PGE2 20-hydroxy prostaglandin E2 \\ 20-HETE 20-hydroxyeicosatetraenoic acid, \\ $(5 Z, 8 Z, 11 Z, 14 Z)$-20-hydroxyicosa- \\ $5,8,11,14$-tetraenoic acid \\ $\alpha$ SMAD alpha-smooth muscle actin
}

ABC294640 small-molecule 3-(4-chlorophenyl)-adamantane-1-carboxylic acid (pyridin-4ylmethyl) amide sphingosine kinase (SK) inhibitor

AK081284 long noncoding RNA-AK081284

AIDS

Akt

ALOX

ALOX12 acquired immune deficiency syndrome protein kinase $\mathrm{B}$ (PKB)

lipoxygenase, arachidonate lipoxygenase 12-lipoxygenase, 12-LOX, 12S-LOX, arachidonate 12-lipoxygenase $12 \mathrm{~S}$ type

ALOX5 5-lipoxygenase, 5-LOX, arachidonate 5 -lipoxygenase

AP1 activator protein 1

APC

$\mathrm{AOM}$

AOPP

AQP

AQP1

AQP3

AQP4

AQP5

AQP7

AQP8

AQP9

ATF-3

AT-Cox 2

Bcl-2

BIM

adenomatous polyposis coli

azoxymethane

advanced oxidative protein products

aquaporines

aquaporine 1

aquaporine 3

aquaporine 4

aquaporine 5

aquaporine 7

aquaporine 8

aquaporine 9

cyclic AMP-dependent transcription factor aspirin-triggered cyclooxygenase 2

B-cell lymphoma 2

$\mathrm{BPH}$ benign prostate hyperplasia 


\begin{tabular}{|c|c|c|c|}
\hline \multirow[t]{3}{*}{ CFTR Cl } & cystic fibrosis transmembrane conduc- & GTP & guanosine- 5 '-triphosphate \\
\hline & tance regulator (CFTR) and chloride & $\mathrm{HBV}$ & hepatitis B virus \\
\hline & channel $\left(\mathrm{Cl}^{-}\right)$ & $\mathrm{HCC}$ & hepatocellular carcinoma \\
\hline c-c-motif & chemokine & $\mathrm{HCO}^{-}$ & hydrogen carbonate \\
\hline cadherin-1 & E-cadherin & $\mathrm{HCV}$ & hepatitis $\mathrm{C}$ virus \\
\hline CagA & cytotoxin-associated gene A & HGFR & hepatocyte growth factor receptor \\
\hline $\mathrm{CBA}$ & conjugated bile acid & & (tyrosine-protein kinase Met, c-Met) \\
\hline CCC & cholangiocellular carcinoma & HHV-1 & human herpes virus 1 (HSV-1) \\
\hline \multirow[t]{2}{*}{ CCL20 } & chemokine (C-C motif) ligand 20 , & HHV-2 & human herpes virus 2 (HSV-2) \\
\hline & $\begin{array}{l}\text { macrophage inflammatory protein- } 3 \\
\text { (MIP3A) }\end{array}$ & HHV-3 & $\begin{array}{l}\text { human herpes virus } 3 \text { (varizella zoster } \\
\text { virus, VZV) }\end{array}$ \\
\hline $\mathrm{CD} 4+$ & cluster of differentiation 4 positive & HHV-8 & human herpes virus 8, Kaposi's \\
\hline CD40 & cluster of differentiation 40 & & sarcoma-associated herpes virus (KSHV) \\
\hline CD44 & cluster of differentiation 44 & HIF- $1 \alpha$ & hypoxia-inducible factor \\
\hline \multirow[t]{2}{*}{ CD49C } & cluster of differentiation 49C (integrin & HIV & human immunodeficiency virus \\
\hline & $\begin{array}{l}\text { alpha } 3 \text {, integrin } \alpha 3 \text { ) } \\
\text { cluster of differentiation } 54 \text { (intercellular }\end{array}$ & $\begin{array}{l}\text { HMC } \\
\text { HNSCC }\end{array}$ & $\begin{array}{l}\text { human mesothelial cells } \\
\text { head and neck squamous cell cancer }\end{array}$ \\
\hline CD54 & $\begin{array}{l}\text { cluster of differentiation } 54 \text { (intercellular } \\
\text { adhesion molecule 1, ICAM-1) }\end{array}$ & $\mathrm{HPV}$ & $\begin{array}{l}\text { human papilloma virus } \\
\text { hem canc }\end{array}$ \\
\hline $\operatorname{cdc} 42$ & cell division control protein 42 homolog & HSV & human herpes virus \\
\hline $\operatorname{cdk} 2$ & cyclin-dependent kinase 2 & HSV-1 & human herpes virus 1 (HHV-1) \\
\hline \multirow[t]{2}{*}{ c-Met } & tyrosine-protein kinase Met (hepatocyte & HSV-2 & human herpes virus 2 (HHV-2) \\
\hline & growth factor receptor, HGFR) & HtrA & high temperature requirement $\mathrm{A}$ (serin \\
\hline Cox & cyclooxygenase & & protease) \\
\hline Cox-1 & cyclooxygenase 1 & IBD & inflammatory bowel disease \\
\hline $\begin{array}{l}\text { Cox-2 } \\
(\mathrm{Cox}-3)\end{array}$ & $\begin{array}{l}\text { cyclooxygenase } 2 \\
\text { cyclooxygenase } 2 \text { isoform (Cox-2 isoform) }\end{array}$ & ICAM-1 & $\begin{array}{l}\text { intercellular adhesion molecule } 1 \text { (cluster } \\
\text { of differentiation } 54, \text { CD } 54 \text { ) }\end{array}$ \\
\hline \multirow[t]{2}{*}{ CPS-II } & Cancer Prevention Study II by the & IDO & indoleamine-2,3-dioxygenase \\
\hline & American Cancer Society & $\mathrm{IFN} \gamma$ & interferon gamma \\
\hline $\mathrm{CRC}$ & colorectal cancer & $\mathrm{IHC}$ & immunohistochemistry \\
\hline CRP & C-reactive protein & IL- $\beta 1$ & interleukin beta 1 \\
\hline CSES & chronic stress escape strategy & IL-6 & interleukin 6 \\
\hline $\mathrm{CXC} \mathrm{CC}$ & chemokine receptors & IL-8 & 8 \\
\hline CXCL1 & nemokine $(\mathrm{C}-\mathrm{X}-\mathrm{C}$ motif $)$ ligand 1 & IL-10 & \\
\hline $\mathrm{CXCR} 4$ & $\mathrm{C}-\mathrm{X}-\mathrm{C}$ motif of chemokine receptor 4 & IL-12 & interleukin 12 \\
\hline CYP & cytochrome P450 & IL-17 & interleukin 17 \\
\hline $\mathrm{CYP}^{*}$ & cytochrome $\mathrm{P} 450$ isoforms & IL-17+ & interleukin 17 positive \\
\hline DNA & deoxyribonucleic acid & IL-22 & interleukin 22 \\
\hline \multirow[t]{3}{*}{$\mathrm{E} 2 \mathrm{~F} 4 / 5$} & cytoplasmic complex of Smad3, retino- & IL-23 & interleukin 23 \\
\hline & blastoma-like protein 1 (P107, RBL1), & IL-33 & \\
\hline & E2F4/5 and d-prostanoid (DP1) & Integrin $\alpha 3$ & integrin alpha 3 (cluster of differentiation \\
\hline EBV & Epstein-Barr virus & & $49 \mathrm{C}, \mathrm{CD} 49 \mathrm{C})$ \\
\hline E-cadherin & $\begin{array}{l}\text { CAM } 120 / 80 \text { or epithelial cadherin, cad- } \\
\text { herin-1, epithelial cadherin }\end{array}$ & Integrin $\beta 1$ & $\begin{array}{l}\text { integrin beta } 1 \text { (cluster of differentiation } \\
29, \text { CD29) }\end{array}$ \\
\hline \multirow{3}{*}{$\begin{array}{l}\mathrm{ECM} \\
\mathrm{EIF}_{2} \mathrm{AK}_{4}\end{array}$} & extracellular matrix & KSHV & Kaposi's sarcoma-associated herpes virus, \\
\hline & eukaryotic translation initiation factor 2- & & human herpes virus 8 (HHV-8) \\
\hline & & LGD & low-grade dysplasia \\
\hline \multirow[t]{2}{*}{$\mathrm{eIF} 2 \alpha$} & eukaryotic translation initiation factor 2 & LPS & lipopolysaccharide \\
\hline & & LOXL3 & homolog 3 \\
\hline EIF2S1 & $\begin{array}{l}\text { eukaryotic translation initiation factor } 2 \\
\text { subunit alpha }(\text { eIF } 2 \alpha)\end{array}$ & LTA4 & $\begin{array}{l}\text { leukotriene A4, 4-[(2S,3S)-3- } \\
{[(1 E, 3 E, 5 Z, 8 Z) \text {-tetradeca-1,3,5,8-tet- }}\end{array}$ \\
\hline ERK1 & mitogen-activated protein kinase 3 & & raenyl|oxiran-2-yl|butanoic acid \\
\hline ERK2 & mitogen-activated protein kinase 1 & LTB4 & leukotriene B4, (5S,6Z,8E,10E,12R,14Z)- \\
\hline ESCC & esophageal squamous cell carcinoma & & 5,12 -dihydroxyicosa- $6,8,10,14$-tetraenoic \\
\hline ETBF & enterotoxigenic Bacteroides fragilis & & acid \\
\hline FAP & familial adenomatous polyposis & LTC4 & leukotriene $\mathrm{C} 4,(5 S, 6 R, 7 E, 9 E, 11 Z, 14 Z)-6-$ \\
\hline FOXO3a & forkhead box protein O3a & & [(2R)-2-[[(4S)-4-amino-4-carboxybuta- \\
\hline FoxP3 & forkhead box protein P3 & & noyl|amino]-3-(carboxymethylamino)-3- \\
\hline Gcn2 & general control nonderepressible 2 & & oxopropyl|sulfanyl-5-hydroxyicosa- \\
\hline GSO & gastric spiral organisms & & 7,9,11,14-tetraenoic acid \\
\hline
\end{tabular}


LTD4

LTE4

LXA4

MALAT1

MAPK

MCD

MDA

MDSC

MIP3A

$\operatorname{miR} 21$

MMP

MMP-1

MMP-2

MMP-3

MMP-7

MMP-9

MMP-14

mTOR

mTORC1

$\mathrm{NF}-\kappa \mathrm{B}$

NCCCT

NFAT

NHE3

NSCLC

OSM

p53

p107

p120

p38 MAPK

p300

PAI1

PCN

PEL

PGG2

PGH2

PGFF $2 \alpha$

PGD2 leukotriene $\mathrm{D} 4,(5 S, 6 R, 7 E, 9 E, 11 Z, 14 Z)$ -

6-[(2R)-2-amino-3-(carboxymethylamino)-3-oxopropyl|sulfanyl-5-hydroxyicosa-7,9,11,14-tetraenoic acid leukotriene $\mathrm{E} 4,(5 S, 6 R, 7 E, 9 E, 11 Z, 14 Z)-6$ [(2R)-2-amino-2-carboxyethyl]sulfanyl-5hydroxyicosa-7,9,11,14-tetraenoic acid lipoxin A4, 5S,6R,15S-trihydroxy$7 E, 9 E, 11 Z, 13 E$-eicosatetraenoic acid metastasis-associated lung adenocarcinoma transcript 1

mitogen-activated protein kinase (see ERK1 and ERK2)

multicentric Castleman disease

malondialdehyde, propanedial

myeloid-derived suppressor cell

macrophage inflammatory protein-3, chemokine (C-C motif) ligand 20 (CCL20)

micro RNA-21

matrix metalloproteinase

metalloproteinase 1 (interstitial

collagenase)

metalloproteinase 2 (gelatinase A)

metalloproteinase 3 (stromelysin-1)

metalloproteinase 7

matrixmetalloproteinase 9 (gelatinase B)

metalloproteinase 14

mechanistic target of rapamycin

rapamycin complex 1

nuclear factor kappa-light-chain-enhanc-

er of activated B cells

normal cell to cancerous cell transition

nuclear factor of activated $\mathrm{T}$ cells

$\mathrm{Na}^{+} / \mathrm{H}^{+}$exchanger

nonsmall cell lung cancer

oncostatin-M

tumor protein p53

retinoblastoma-like protein $1, \mathrm{RBL} 1$

protein 120 , catenin delta-1

p38 mitogen-activated protein kinases

protein 300 (p300-CBP coactivator

family)

plasminogen activator inhibitor-1

precancerous niche

primary effusion lymphoma

prostaglandin G2, $(Z)-7-[(1 S, 4 R, 5 R, 6 R)$ -

5-[(E,3S)-3-hydroperoxyoct-1-enyl]-2,3-

dioxabicyclo[2.2.1]heptan-6-yl]hept-5-

enoic acid

prostaglandin $\mathrm{H} 2,(Z)-7-[(1 S, 4 R, 5 R, 6 R)-$ 5-[(E,3S)-3-hydroxyoct-1-enyl]-2,3-dioxabicyclo[2.2.1]heptan-6-yl|hept-5-enoic acid prostaglandine $\mathrm{F} 2$ alpha, $(Z)-7-[(1 R, 2 R$, $3 R, 5 S)$-3,5-dihydroxy-2-[(E,3S)-3-hydroxyoct-1-enyl]cyclopentyl]hept-5-enoic acid prostaglandin D2, (Z)-7-[(1R,2R,5S)-5hydroxy-2-[(E,3S)-3-hydroxyoct-1-enyl]3-oxocyclopentyl|hept-5-enoic acid
PGE2

prostaglandin E2, $(Z)-7-[(1 R, 2 R, 3 R)-3-$ hydroxy-2-[(E,3S)-3-hydroxyoct-1-enyl]-5oxocyclopentyl]hept-5-enoic acid

PI3K phosphatidylinositide 3-kinase

PKB

PKC

PLCO

PLP

Pro-MMP-1 pro-matrix metalloproteinase 1

Pro-MMP-7 pro-matrix metalloproteinase 7

Pro-MMP-9 pro-matrix metalloproteinase 9

PSC pancreatic stellate cell

PUMA BH3-only protein

Rac1 Ras-related C3 botulinum toxin substrate 1

Rho Ras homolog gene family, member A

RB1CC1 retinoblastoma coiled coil protein 1

ROS

S1P

S1PL2021 homologous protein to S1PL2025, encoded by Burkholderia pseudomallei K96243

S1PL2025 homologous protein to S1PL2021, encoded by Burkholderia pseudomallei K96243

\section{S1PL S1P lyase}

S1PR2 S1P receptor 2

S1PR3 S1P receptor 3

SGLT1 sodium - glucose transport protein 1

SIP1 Smad interacting protein 1

SK2 sphingosine kinase 2

SNAIL zinc finger protein SNAI1

SOX [sex-determining region Y (Sry) box-containing] transcription factor family

SP1 specificity protein 1

SphK sphingosine kinase isoform

SphK1 sphingosine kinase isoform 1

SphK2 sphingosine kinase isoform 2

SSeCKS src-suppressed C-kinase substrate

STH

T4SSs

TA

TGF- $\beta 1$

$\mathrm{TNF} \alpha$

Tregs

TXA2

VCAM-1

VZV

$\mathrm{ZnPP}$

\section{Acknowledgement}

The manuscripts of this Special Issue were supported by the Theodor-Billroth-Academy ${ }^{\circledR} \quad\left(\mathrm{TBA}^{\circledR}\right)$ and INCORE, (International Consortium of Research Excellence) of the $\left(\mathrm{TBA}^{\circledR}\right)$. We express our gratitude to the 
discussions on the web group of the Theodor-BillrothAcademy on LinkedIn, the exchange with scientists at Researchgate.com, as well as personal exchanges with distinguished colleagues who stimulated our thinking all named individually earlier in publications - we thank each one. We further gratefully acknowledge the support of Marjan S. Rupnik, PhD, Professor of Physiology, Institute of Physiology, Center for Physiology and Pharmacology, Medical University of Vienna, Austria, for pre-submission review of the literature and our fruitful discussions.

\section{Conflict of interest}

The author reports the following conflict of interest: Björn LDM Brücher is Editor-in-Chief in Life SciencesMedicine of 4open by EDP Sciences. Ijaz S. Jamall is Senior Editorial Board member in Life Sciences-Medicine of 4open by EDP Sciences. The authors, of their own initiative, suggested to the Managing Editorial to perform a transparent peer-review of their submittals. Neither author took any action to influence the standard submission and peer-review process, and report no conflict of interest. The authors alone are responsible for the content and writing of the manuscript of this Special Issue. This manuscript contains original material that has not previously been published. Both authors contributed to the discussion on its contents and approved the manuscript.

\section{References}

1. Pott P (1755), Chirurgical observations, vol. 3, L Hawes, W Clark, and R Collins, London, pp. 177-183.

2. Horner WE (1829), A treatise on pathological anatomy, Carey, Lea \& Carey, Philadelphia.

3. Dutrochet MH (1824), Recherches anatomiques et physiologiques sur la structure intime animaux et des végétaux, et sur leur motilité, Bailliere, Paris.

4. Addison W (1843), Experimental and practical researches on the structure and function of blood corpuscles; on inflammation; and on the origin and nature of tubercles in the lungs. Tr Provinc Med Surg Ass 11, 233-306.

5. Waller A (1846), Microscopic examination of some of the principal tissues of the animal frame, as observed in the tongue of the living forg, toad, London, Edinburgh and Dublin. Philos Mag 29, 271-287.

6. Brown WN (1857), Case in which inflammation and ulceration of the sound skin was caused by the application of a strong arsenical solution. Edinb Med J 3, 148-149.

7. Virchow R (1863), Über bewegliche tierische Zellen. Arch Path Anat Physiol 28, 237-240.

8. Cohnheim JF (1867), Über Entzündung und Eiterung. Virchows Arch 40, 1-79.

9. Cohnheim JF (1889), Inflammation, in: Lectures on General Pathology, The New Sydenham Society, London, p. 242.

10. Malkin HM (1984), Julius Cohnheim (1839-1884): his life and contributions to pathology. Ann Clin Lab Sci 14, $335-342$
11. Bryant T (1868), Remarks on some cases of inflammation of the breast simulating cancer. Br Med J 2, 608-609.

12. Eve FS (1881), On the relation of epithelioma to irritation and chronic inflammation. Br Med J 1, 504-506.

13. Arnold J (1873), Über Diapedesis, eine experimentelle Studie. Virchows Arch 58, 203-254.

14. Arnold J (1887), Über Theilungsvorgänge an den Wanderzellen, ihre progressiven und regressiven Metamorphosen. Arch Mikroskop Anat 30, 205-310.

15. Arnold J (1888), Über die Entstehung der Entzündung und die Wirkung der entzündungserregenden Schädlichkeiten. Fortschr Med 4, 460.

16. Metchnikoff E (1883), Untersuchungen über die intracellulare Verdauung bei wirbellosen Tieren. Arb Zool Inst Univ Wien 5, 141-168.

17. Metschnikoff E (1884), Üeber eine Sprosspilzkrankheit der Daphnien. Beitrag zur Lehre über den Kampf der Phagocyten gegen Krankheitserreger. Virchows Arch 96, 177-195.

18. Brücher BLDM, Jamall IS (2014), Epistemology of the origin of cancer: a new paradigm. BMC Cancer 14, $1-15$.

19. Brücher BLDM, Jamall IS (2014), Cell-cell communication in tumor microenvironment, carcinogenesis and anticancer treatment. Cell Physiol Biochem 34, 213-243.

20. Van Tongeren M, Jimenez AS, Hutchings SJ, MacCalman L, Rushton L, Cherrie JW (2012), Occupational cancer in Britain: exposure assessment methodology. Br J Cancer 107, S18-S26.

21. Beir V (1990), Health effects of exposure to low levels of ionizing radiation: National Research Council (US) Committee on the Biological Effects of Ionizing Radiation (BEIR V), National Academies Press (US), Washington DC. ISBN-10: 0-309-03995-9.

22. Curtis HJ (1965), Formal discussion of somatic mutations and carcinogenesis. Cancer Res 25, 1305-1308.

23. Brücher BLDM, Jamall IS (2016), Somatic mutation theory - why it's wrong for most cancers. Cell Physiol Biochem 38, 1663-1680.

24. Rehrauer H, Wu L, Blum W, Pecze L, Henzi T, SerreBeinier V, Aquino C, Vrugt B, de Perrot M, Schwaller B, Felley-Bosco E (2018), How asbestos drives the tissue towards tumors: YAP activation, macrophage and mesothelial precursor recruitment, RNA editing, and somatic mutations. Oncogene 37, 2645-2659.

25. Boll M, Weber LW, Becker E, Stampfl A (2001), Mechanism of carbon tetrachloride-induced hepatotoxicity: hepatocellular damage by reactive carbon tetrachloride metabolites. Z Naturforsch C 56, 649-659.

26. Irshad M, Gupta P, Irshad K (2017), Molecular basis of hepatocellular carcinoma induced by hepatitis $\mathrm{C}$ virus infection. World J Hepatol 9, 1305-1314.

27. Maden C, Beckmann AM, Thomas DB, McKnight B, Sherman KJ, Ashley RL, Corey L, Daling JR (1992), Human papillomaviruses, herpes simplex viruses, and the risk of oral cancer in men. Am J Epidemiol 135, 1093-1102.

28. Cobos C, Figueroa JA, Mirandola L, Colombo M, Summers G, Figueroa A, Aulakh A, Konala V, Verma R, Riaz J, Wade R, Saadeh C, Rahman RL, Pandey A, Radhi S, Nguyen DD, Jenkins M, Chiriva-Internati M, Cobos E (2014), The role of human papilloma virus (HPV) infection in non-anogenital cancer and the promise of immunotherapy: a review. Int Rev Immunol 33, 383-401.

29. Correia AV, Coêlho MR, de Oliveira Mendes Cahú GG, de Almeida Silva JL, da Mota Vasconcelos Brasil C, de Castro JF (2015), Seroprevalence of HSV-1/2 and correlation with aggravation of oral mucositis in patients 
with squamous cell carcinoma of the head and neck region submitted to antineoplastic treatment. Support Care Cancer 23, 2105-2111.

30. Sano D, Oridate N (2016), The molecular mechanism of human papillomavirus-induced carcinogenesis in head and neck squamous cell carcinoma. Int J Clin Oncol 21, 819-826.

31. Villeneuve PJ, Mao Y (1994), Lifetime probability of developing lung cancer, by smoking status, Canada. Can J Public Health 85, 385-388.

32. Yamagiwa K, Ichikawa K (1915), Experimentelle Studie über die Pathogenese der Epithelialgeschwülste [Experimental study of the pathogenesis of epithelial tumours. Mitt Med Fak Tokyo 15, 295-344.

33. Brücher BLDM, Stein HJ, Bartels H, Feussner H, Siewert JR (2001), Achalasia and esophageal cancer: incidence, prevalence and prognosis. World J Surg 25, 745-749.

34. Zeng Y (2017), Endothelial glycocalyx as a critical signalling platform integrating the extracellular haemodynamic forces and chemical signaling. J Cell Mol Med 21, 1457-1462.

35. Potter DR, Jiang J, Damiano ER (2009), The recovery time course of the endothelial cell glycocalyx in vivo and its implications in vitro. Circ Res 104, 1318-1325.

36. McDonald KK, Cooper S, Danielzak L, Leask RL (2016), Glycocalyx degradation induces a proinflammatory phenotype and increased leukocyte adhesion in cultured endothelial cells under flow. PLoS One 11, e0167576.

37. Qazi H, Palomino R, Shi ZD, Munn LL, Tarbell JM (2013), Cancer cell glycocalyx mediates mechanotransduction and flow-regulated invasion. Integr Biol (Camb) 5, 1334-1343.

38. Wagner BJ, Löb S, Lindau D, Hörzer H, Gückel B, Klein G, Glatzle J, Rammensee HG, Brücher BLDM, Königsrainer A (2011), Simvastatin reduces tumor cell adhesion, to human peritoneal mesothelial cells by a decreased expression of VCAM-1 and $\beta 1$ integrin. Int $\mathrm{J}$ Oncol 39, 1593-1600.

39. Porfire A, Tomuta I, Muntean D, Luca L, Licarete E, Alupei MC, Achim M, Vlase L, Banciu M (2015), Optimizing longcirculating liposomes for delivery of simvastatin to C26 colon carcinoma cells. J Liposome Res 25, 261-269.

40. Zeng YE, Yao XH, Yan ZP, Liu JX, Liu XH (2016), Potential signaling pathway involved in sphingosine-1phosphate-induced epithelial-mesenchymal transition in cancer. Oncol Lett 12, 379-382.

41. Zeng Y, Liu XH, Tarbell J, Fu B (2015), Sphingosine 1phosphate induced synthesis of glycocalyx on endothelial cells. Exp Cell Res 339, 90-95.

42. Levi-Schaffer F, Austen KF, Gravallese PM, Stevens RL (1986), Coculture of interleukin 3-dependent mouse mast cells with fibroblasts results in a phenotypic change of the mast cells. Proc Natl Acad Sci USA 83, 6485-6488.

43. Schwalm S, Pfeilschifter J, Huwiler A (2013), Sphingosine-1-phosphate: a Janus-faced mediator of fibrotic diseases. Biochim Biophys Acta 1831, 239-250.

44. Oskeritzian CA (2015), Mast cell plasticity and sphingosine-1-phosphate in immunity, inflammation and cancer. Mol Immunol 63, 104-112.

45. Spiegel S, Milstien S (2007), Functions of the multifaceted family of sphingosine kinases and some close relatives. J Biol Chem 282, 2125-2129.

46. Vadas M, Xia P, McCaughan G, Gamble J (2008), The role of sphingosine kinase 1 in cancer: oncogene or non-oncogene addiction? Biochim Biophys Acta 1781, 442-447.

47. Zhu YJ, You H, Tan JX, Li F, Qiu Z, Li HZ, Huang HY, Zheng K, Ren GS (2017), Overexpression of sphingosine kinase 1 is predictive of poor prognosis in human breast cancer. Oncol Lett 14, 63-72.

48. Maceyka M, Payne SG, Milstien S, Spiegel S (2002), Sphingosine kinase, sphingosine-1-phosphate, and apoptosis. Biochim Biophys Acta 1585, 193-201.

49. Cuvillier O, Pirianov G, Kleuser B, Vanek PG, Coso OA, Gutkind S, Spiegel S (1996), Suppression of ceramidemediated programmed cell death by sphingosine-1phosphate. Nature 381, 800-803.

50. Milstien S, Spiegel S (2006), Targeting sphingosine-1phosphate: a novel avenue for cancer therapeutics. Cancer Cell 9, 148-150.

51. Lee HM, Lo KW, Wei W, Tsao SW, Chung GTY, Ibrahim MH, Dawson CW, Murray PG, Paterson IC, Yap LF (2017), Oncogenic S1P signalling in EBV-associated nasopharyngeal carcinoma activates $\mathrm{AKT}$ and promotes cell migration through S1P receptor 3. J Pathol 242, 62-72.

52. Riddell RH, Goldman H, Ransohoff DF, Appelman HD, Fenoglio CM, Haggitt RC, Ahren C, Correa P, Hamilton SR, Morson BC, Sommers SC, Yardley JH (1983), Dysplasia in inflammatory bowel disease: standardized classification with provisional clinical applications. Hum Pathol 14, 931-968.

53. Wollny T, Wątek M, Durnas B, Niemirowicz K, Piktel E, Zendzian-Piotrowska M, Gózdz S, Bucki R (2017), Sphingosine-1-phosphate metabolism and its role in the development of inflammatory bowel disease. Int J Mol Sci 18, pii: E741.

54. McLean CJ, Marles-Wright J, Custodio R, Lowther J, Kennedy AJ, Pollock J, Clarke DJ, Brown AR, Campopiano DJ (2017), Characterization of homologous sphingosine-1phosphate lyase isoforms in the bacterial pathogen Burkholderia pseudomallei. J Lipid Res 58, 137-150.

55. Deng Z, Mu J, Tseng M, Wattenberg B, Zhuang X, Egilmez NK, Wang Q, Zhang L, Norris J, Guo H, Yan J, Haribabu B, Miller D, Zhang HG (2015), Enterobacteriasecreted particles induce production of exosome-like S1P-containing particles by intestinal epithelium to drive Th17-mediated tumorigenesis. Nat Commun 6, 6956 (corrigendum: Nat Commun 2016, 7, 11348).

56. Hendley AM, Wang YJ, Polireddy K, Alsina J, Ahmed I, Lafaro KJ, Zhang H, Roy N, Savidge SG, Cao Y, Hebrok M, Maitra A, Reynolds AB, Goggins M, Younes M, IacobuzioDonahue CA, Leach SD, Bailey JM (2016), p120 catenin suppresses basal epithelial cell extrusion in invasive pancreatic neoplasia. Cancer Res 76, 3351-2263.

57. Studer E, Zhou X, Zhao R, Wang Y, Takabe K, Nagahashi M, Pandak WM, Dent P, Spiegel S, Shi R, Xu W, Liu X, Bohdan P, Zhang L, Zhou H, Hylemon PB (2012), Conjugated bile acids activate the sphingosine-1phosphate receptor 2 in primary rodent hepatocytes. Hepatology 55, 267-276.

58. Zhou H, Hylemon PB (2014), Bile acids are nutrient signaling hormones. Steroids 86, 62-68.

59. Liu R, Li X, Qiang X, Luo L, Hylemon PB, Jiang Z, Zhang L, Zhou H (2015), Taurocholate induces cyclooxygenase-2 expression via the sphingosine 1-phosphate receptor 2 in a human cholangiocarcinoma cell line. J Biol Chem 290, 30988-31002.

60. French K, Zhuang Y, Maines LW, Gao P, Wang W, Beljanski V, Upson JJ, Green CL, Keller SN, Smith CD (2010), Pharmacology and antitumor activity of ABC294640, a selective inhibitor of sphingosine kinase-2. J Pharmacol Exp Ther 333, 129-139.

61. Qin Z, Dai L, Trillo-Tinoco J, Senkal C, Wang W, Reske T, Bonstaff K, Del Valle L, Rodriguez P, Flemington E, Voelkel-Johnson C, Smith CD, Ogretmen B, Parsons C 
(2014), Targeting sphingosine kinase induces apoptosis and tumor regression for KSHV-associated primary effusion lymphoma. Mol Cancer Ther 13, 154-164.

62. Cumston CG (1926), The history of herpes from the earliest times to the nineteenth century. Ann Med Hist 8, 284-291.

63. Papyrus E (1937), Greatest Egyptian medical document, 1552 BC, translated by Ebbell B, Levin \& Munksgaard, Copenhagen.

64. Wildy P (1973), Herpes: history and classification, in: AS Kaplan (Ed.), The Herpes Viruses Academic Press, New York, pp. 1-25.

65. Roizman B, Whitley R (2001), The nine ages of herpes simplex virus. Herpes 8, 23-27.

66. Littré E (1839-1861), Oeuvres complètes d'Hippocrate: traduction nouvelle avec le texte grec en regard, collationné sur les manuscrits et toutes les éditions; accompagnée d'une introduction, de commentaires médicaux, de variantes et de notes philologiques; suivie d'une table générale des matières. Exemplaire numérisé, vols. 110, BIU Santé, Paris, Baillière.

67. Tsoucalas G, Karamanou M, Sgantzos M, Deligeoroglou E, Androutsos G (2015), Uterine cancer in the writings of ancient Greek physicians. J BUON 20, 1382-1385.

68. Galien C (1994), Oeuvres médicales choisies: des facultés naturelles, des lieux affectés, de la méthode thérapeutique à Glaucon, in: A Pichot (Ed.), translated by Daremberg C, Gallimard pp. 323-327. ISBN 2070736857.

69. Astruc J (1736), De Morbis Venereis Libri Sex, G Cavelier, Paris.

70. Vidal E (1873), Inoculabilité des pustules d'ecthyma. Ann Dermatol Syphiligr II, 350-358.

71. Steiner (1875), Zur Inokulation der Varicellen. Wiener Medizinische Wochenschrift 16, 305-308.

72. Unna PG (1883), On herpes progenitalis, especially in women. J Cutan Veneral Dis 1, 321-334.

73. Kelsch A, Kiener PL (1876), Contribution â l'histoire de l'adénome du foie. Arch Physiol S II 3, 622.

74. Hanot V, Gilbert A (1888), Etudes sur les maladies du foie, Asselin and Houzeau, Paris.

75. Virchow R (1855), Handbuch der speziellen Pathologie und Therapie, F. Enke, Erlangen und Stuttgart.

76. Yamagiwa K (1911), Zur Kenntnis des primären parenchymatösen Leberkarzinoms, Virchow Arch Path Anat 206, 437-467.

77. Goldzieher M, von Bokay Z (1911), Der primäre Leberkrebs. Virchow Arch Path Anat 203, 75-131.

78. Sabourin C (1881), Contribution à l'étude des lesions du parenchyme hépatique dans la cirrhose. Essai sur l'adenome du foie, Thèse Paris.

79. Holley HL, Pierson G (1948), Primary carcinoma of the liver. Am J Med 5, 561-569.

80. Sheldon WH, James DF (1948), Cirrhosis following infectious hepatitis: a report of five cases, in two of which there was superimposed primary liver cell carcinoma. Arch Intern Med (Chic) 81, 666-689.

81. Prince AM, Leblanc L, Krohn K, Masseyeff R, Alpert ME (1970), S.H. antigen and chronic liver disease. Lancet 2, 717-718.

82. Sherlock S, Fox RA, Niazi SP, Scheuer PJ (1970), Chronic liver disease and primary liver-cell cancer with hepatitis associated (Australia) antigen in serum. Lancet 1, 12431247.

83. Szmunes W (1978), Hepatocellular carcinoma and the hepatitis B virus: evidence for a causal association. Prog Med Virol 24, 40-69.

84. Katsurada F (1900), Beitrag zur Kenntnis des Distomum spatulatum. Heif Pathol Anal 28, 479-505.
85. Hou PC (1955), The pathology of Clorrorchis sinensis infestation of the liver. J Pathol Bact 70, 53-64.

86. Nakashima T, Sakamoto K, Okuda K (1977), A minute hepatocellular carcinoma found in a liver with clonorchis sinensis infection: report of two cases. Cancer 39, 13061311.

87. Burkitt D (1958), A sarcoma involving the jaws in African children. Br J Surg 46, 218-223.

88. Epstein MA, Achong BG, Barr YM (1964), Virus particles in cultured lymphoblasts from Burkitt's lymphoma. Lancet 1, 702-703.

89. Finkel MP, Biskis BO, Farrell C (1968), Osteosarcomas appearing in Syrian hamsters after treatment with extracts of human osteosarcomas. Proc Natl Acad Sci USA $60,1223-1230$.

90. Pritchard DJ, Reilly CA, Finkel MP (1971), Evidence for a human osteosarcomavirus. Nat New Biol 234, 126-127.

91. Balabanova H, Kotler M, Becker Y (1975), Transformation of cultured human embryonic fibroblasts by oncornavirus-like particles released from a human carcinoma cell line. Proc Natl Acad Sci USA 72, 2794-2798.

92. Cook B, O'Sullivan F, Leung J, Morse P, Graham B, Chapman AL (1978), Transformation of human embryo cells with the use of cell-free extracts of a human rhabdomyosarcoma cell line (HUS-2). J Natl Cancer Inst 60, 979-984.

93. Epstein AL, Kaplan HS (1974), Biology of the human malignant lymphomas. I. Establishment in continuous cell culture and heterotransplantation of diffuse histiocytic lymphomas. Cancer 34, 1851-1972.

94. Kaplan HS, Goodenow RS, Epstein AL, Gartner S, Decleve A, Rosenthal PN (1977), Isolation of a type of C RNA virus from an established human histiocytic lymphoma cell line. Proc Natl Acad Sci USA 74, 25642568 .

95. Kaplan HS (1978), Studies of an RNA virus isolated from a human histiocytic lymphoma cell line, Cold Spring Harbor Conf. Cell Proliferation 5, 695-706. In: Differentiation of normal and neoplastic hematopoietic cells [Cold Spring Harbor, N. Y.]: Cold Spring Harbor Laboratory, 1978. NLM Unique ID: 101114935.

96. Kaplan HS Goodenow RS, Gartner S, Bieber MM (1979), Biology and virology of the human malignant lymphomas. Cancer 43, 1-24.

97. Henle W, Henle G (1980), Epidemiologic aspects of Epstein-Barr-Virus (EBV)-associated diseases. Ann N Y Acad Sci 354, 326-331.

98. De The G (1979), The epidemiology of Burkitt's lymphoma: evidence for a causal association with Epstein-Barr virus. Epidemiol Rev 1, 32-54.

99. Henle W, Diehl V, Kohn G, zur Hausen H, Henle G (1967), Herpes-type virus and chromosome marker in normal leukocytes after growth irradiated Burkitt cells. Science 157, 1064-1065.

100. Slavins HE, Gavett E (1946), Primary herpetic vulvovaginitis. Proc Soc Exp Med 63, 343-345.

101. Frost JK (1961), Cytology of benign conditions. Clin Obstet Gynecol 4, 1075-1096.

102. Kotcher E, Gray LA, James QC, Frick CA, Bottorff DW (1962), Cervical cell inclusion bodies and viral infection of the cervix. Ann N Y Acad Sci 97, 571-580.

103. Varga A, Browell B (1960), Viral inclusion bodies in vaginal smears. Obstet Gynec 16, 441-444.

104. Naib ZM, Nahmias AJ, Josey WE (1966), Cytology and histopathology of cervical herpes simplex infection. Cancer 19, 1026-1031. 
105. Rawls WE, Tompkins WA, Figueroa ME, Melnick JL (1968), Herpesvirus type 2: association with carcinoma of the cervix. Science 161, 1255-1256.

106. Rawls WE, Tompkins WA, Melnick JL (1969), The association of herpesvirus type 2 and carcinoma of the uterine cervix. Am J Epidemiol 89, 547-554.

107. Nahmias AJ, Naib ZM, Josey WE, Murphy FA, Luce CF (1970), Sarcomas after inoculation of newborn hamsters with Herpes virus hominis type 2 strains. Proc Soc Exp Biol Med 134, 1065-1069.

108. Royston I, Aurelian L, Davis HJ (1970), Genital herpes virus findings in relation to cervical neoplasia. J Reprod Med 4, 9-13.

109. Adam E, Levy AH, Rawls WE, Melnick JL (1971), Seroepidemiologic studies of herpesvirus type 2 and carcinoma of the cervix. I. Case-control matching. J Natl Cancer Inst 47, 941-951.

110. Frenkel N, Roizman B, Cassai E, Nahmias A (1972), A DNA fragment of herpes simplex 2 and its transcription in human cervical cancer tissue. Proc Natl Acad Sci USA 69, 3784-3789.

111. Rawls WE, Adam E, Melnick JL (1973), An analysis of seroepidemiological studies of herpesvirus type 2 and carcinoma of the cervix. Cancer Res 33, 1477-1482.

112. Thomas DB, Rawls WE (1978), Relationship of herpes simplex virus type-2 antibodies and squamous dysplasia to cervical carcinoma in situ. Cancer 42, 2716-2725.

113. Roizman B, Carmichael LE, Deinhardt F, de-The G, Nahmias AJ, Plowright W, Rapp F, Sheldrick P, Takahashi M, Wolf K (1981), Herpesviridae - definition, provisional nomenclature, and taxonomy. The Herpesvirus Study Group, the International Committee on Taxonomy of Viruses. Intervirology 16, 201-217.

114. Kaposi M (1872), Idiopathisches multiples Pigmentsarkom der Haut. Arch Dermatol Syph 4, 265-273.

115. Karamanou M, Antoniou C, Stratigos AJ, Saridaki Z, Androutsos G (2013), The eminent dermatologist Moriz Kaposi (1837-1902) and the first description of idiopathic multiple pigmented sarcoma of the skin. J BUON 18, 1101-1105.

116. Friedman-Kien AE (1981), Disseminated Kaposi's sarcoma syndrome in young homosexual men. J Am Acad Dermatol 5, 468-471.

117. Chang JT, Shebl FM, Pfeiffer RM, Biryahwaho B, Graubard BI, Mbulaiteye SM (2013), A population-based study of Kaposi sarcoma-associated herpesvirus seropositivity in Uganda using principal components analysis. Infect Agent Cancer 8, 9378-9383.

118. Pisani P, Parkin DM, Muñoz N, Ferlay J (1997), Cancer and infection: estimates of the attributable fraction in 1990. Cancer Epidemiol Biomarkers Prev 6, 387-400.

119. Walboomers JM, Jacobs MV, Manos MM, Bosch FX, Kummer JA, Shah KV, Snijders PJ, Peto J, Meijer CJ, Muñoz N (1999), Human papillomavirus is a necessary cause of invasive cervical cancer worldwide. J Pathol 189, 12-19.

120. Jin YT, Tsai ST, Li C, Chang KC, Yan JJ, Chao WY, Eng HL, Chou TY, Wu TC, Su IJ (1997), Prevalence of human papillomavirus in middle ear carcinoma associated with chronic otitis media. Am J Pathol 150, 1327-1333.

121. Senba M, Mori N, Wada A, Fujita S, Yasunami M, Irie S, Hayashi T, Igawa T, Kanetake H, Takahara O, Toriyama K (2010), Human papillomavirus genotypes in penile cancers from Japanese patients and HPV-induced NF-кB activation. Oncol Lett 1, 267-272.

122. Boccardo E, Lepique AP, Villa LL (2010), The role of inflammation in HPV carcinogenesis. Carcinogenesis 31, 1905-1912.
123. Rettig EM, Wentz A, Posner MR, Gross ND, Haddad RI, Gillison ML, Fakhry C, Quon H, Sikora AG, Stott WJ, Lorch JH, Gourin CG, Guo Y, Xiao W, Miles BA, Richmon JD, Andersen PE, Misiukiewicz KJ, Chung CH, Gerber JE, Rajan SD, D'Souza G (2015), Prognostic implication of persistent human papillomavirus type 16 DNA detection in oral rinses for human papillomavirusrelated oropharyngeal carcinoma. JAMA Oncol 1, 907-915.

124. Sgaramella N, Coates PJ, Strindlund K, Loljung L, Colella G, Laurell G, Rossiello R, Muzio LL, Loizou C, Tartaro G, Olofsson K, Danielsson K, Fåhraeus R, Nylander K (2015), Expression of p16 in squamous cell carcinoma of the mobile tongue is independent of HPV infection despite presence of the HPV-receptor syndecan-1. Br J Cancer $113,321-326$.

125. Mehryar MM, Li SY, Liu HW, Li F, Zhang F, Zhou YB, Zeng Y, Li (2015), Prevalence of human papillomavirus in esophageal carcinoma in Tangshan, China. World J Gastroenterol 21, 2905-2911.

126. Moreas H, Tsiambas E, Lazaris AC, Nonni A, Karameris A, Metaxas GE, Armatas HE, Patsouris E (2014), Impact of HPV detection in colorectal adenocarcinoma: HPV protein and chromogenic in situ hybridization analysis based on tissue microarrays. J BUON 19, 91-96.

127. Li YX, Zhang L, Simayi D, Zhang N, Tao L, Yang L, Zhao J, Chen YZ, Li F, Zhang WJ (2015), Human papillomavirus infection correlates with inflammatory Stat3 signaling activity and IL-17 level in patients with colorectal cancer. PLoS One 10, e0118391.

128. Xiong WM, He F, Xiao RD, Yu TT, Zhang X, Liu ZQ, Xu QP , Cai L (2016), Association between human papillomavirus infection and lung cancer. Zhonghua Liu Xing Bing Xue Za Zhi 37, 1658-1661.

129. Lin FC, Huang JY, Tsai SC, Nfor ON, Chou MC, Wu MF, Lee CT, Jan CF, Liaw YP (2016), The association between human papillomavirus infection and female lung cancer: a population-based cohort study. Medicine (Baltimore) 95, e3856.

130. Ilahi NE, Anwar S, Noreen M, Hashmi SN, Murad S (2016), Detection of human papillomavirus-16 DNA in archived clinical samples of breast and lung cancer patients from North Pakistan. J Cancer Res Clin Oncol 142, 2497-2502.

131. Li J, Ding J, Zhai K (2015), Detection of human papillomavirus DNA in patients with breast tumor in China. PLoS One 10, e0136050.

132. Levy E, Carman MD, Fernandez-Madrid IJ, Power MD, Lieberburg I, van Duinen SG, Bots GT, Luyendijk W, Frangione B (1990), Mutation of the Alzheimer's disease amyloid gene in hereditary cerebral hemorrhage, Dutch type. Science 248, 1124-1126.

133. Chartier-Harlin MC, Crawford F, Houlden H, Warren A, Hughes D, Fidani L, Goate A, Rossor M, Roques P, Hardy J, Mullan M (1991), Early-onset Alzheimer's disease caused by mutations at codon 717 of the beta-amyloid precursor protein gene. Nature 353, 844-846.

134. Hendriks L, van Duijn CM, Cras P, Cruts M, Van Hul W, van Harskamp F, Warren A, McInnis MG, Antonarakis SE, Martin JJ, et al. (1992), Presenile dementia and cerebral haemorrhage linked to a mutation at codon 692 of the betaamyloid precursor protein gene. Nat Genet 1, 218-221.

135. Mullan M, Crawford F (1993), Genetic and molecular advances in Alzheimer's disease. Trends Neurosci 16, 398403.

136. Cacace R, Sleegers K, Van Broeckhoven C (2016), Molecular genetics of early-onset Alzheimer's disease revisited. Alzheimers Dement 12, 733-748. 
137. Itzhaki RF, Lathe R (2018), Herpes viruses and senile dementia: first population evidence for a causal link. J Alzheimers Dis 64, 363-366.

138. Marshall BJ (1985), The pathogenesis of non-ulcer dyspepsia. Med J Aust 143, 319.

139. Brücher BLDM, Jamall IS (2019), Precancerous niche $(\mathrm{PCN})$, a product of fibrosis with remodeling by incessant chronic inflammation. 4open 2, 11, 1-21, https://doi.org/ 10.1051/fopen/2018009

140. Yamasaki K, Suematsu H, Takahashi T (1998), Comparison of gastric lesions in dogs and cats with and without gastric spiral organisms. J Am Vet Med Assoc 212, $529-533$.

141. Kubota-Aizawa S, Ohno K, Fukushima K, Kanemoto H, Nakashima K, Uchida K, Chambers JK, Goto-Koshino Y, Watanabe T, Sekizaki T, Mimuro H, Tsujimoto H (2017), Epidemiological study of gastric Helicobacter spp. in dogs with gastrointestinal disease in Japan and diversity of Helicobacter heilmannii sensu stricto. Vet $\mathrm{J}$ 225, 56-62.

142. Zamani M, Vahedi A, Maghdouri Z, Shokri-Shirvani J (2017), Role of food in environmental transmission of Helicobacter pylori. Caspian J Intern Med 8, 146-152.

143. Tegtmeyer N, Wessler S, Necchi V, Rohde M, Harrer A, Rau TT, Asche CI, Boehm M, Loessner H, Figueiredo C, Naumann M, Palmisano R, Solcia E, Ricci V, Backert S (2017), Helicobacter pylori employs a unique basolateral type IV secretion mechanism for CagA delivery. Cell Host Microbe 22, 552-560.

144. Chandran Darbari V, Waksman G (2015), Structural biology of bacterial type IV secretion systems. Annu Rev Biochem 84, 603-629.

145. Li N, Tang B, Jia YP, Zhu P, Zhuang Y, Fang Y, Li Q, Wang K, Zhang WJ, Guo G, Wang TJ, Feng YJ, Qiao B, Mao XH, Zou QM (2017), Helicobacter pylori CagA protein negatively regulates autophagy and promotes inflammatory response via c-Met-PI3K/Akt-mTOR signaling pathway. Front Cell Infect Microbiol 7, 417.

146. Goedert JJ, Hua X, Bielecka A, Okayasu I, Milne GL, Jones GS, Fujiwara M, Sinha R, Wan Y, Xu X, Ravel J, Shi J, Palm NW, Feigelson HS (2018), Postmenopausal breast cancer and oestrogen associations with the $\operatorname{IgA}$ coated and IgA-noncoated faecal microbiota. Br J Cancer $118,471-479$.

147. Thompson KJ, Ingle JN, Tang X, Chia N, Jeraldo PR, Walther-Antonio MR, Kandimalla KK, Johnson S, Yao JZ, Harrington SC, Suman VJ, Wang L, Weinshilboum RL, Boughey JC, Kocher JP, Nelson H, Goetz MP, Kalari KR (2017), A comprehensive analysis of breast cancer microbiota and host gene expression. PLoS One 12, $\mathrm{e} 0188873$.

148. Janda JM, Abbott SL (2007), 16S rRNA gene sequencing for bacterial identification in the diagnostic laboratory: pluses, perils, and pitfalls. J Clin Microbiol 45, 2761-2764.

149. Hayes RB, Ahn J, Fan X, Peters BA, Ma Y, Yang L, Agalliu I, Burk RD, Ganly I, Purdue MP, Freedman ND, Gapstur SM, Pei Z (2018), Association of oral microbiome with risk for incident head and neck squamous cell cancer. JAMA Oncol 4, 358-365.

150. Kumarasamy V, Kuppusamy UR, Jayalakshmi P, Samudi C, Ragavan ND, Kumar S (2017), Exacerbation of colon carcinogenesis by Blastocystis sp. PLoS One 12, e0183097.

151. Banerjee D, Madhusoodanan UK, Nayak S, Jacob J (2003), Urinary hydrogen peroxide: a probable marker of oxidative stress in malignancy. Clin Chim Acta 334, 205-209.
152. Xuan C, Shamonki JM, Chung A, Dinome ML, Chung M, Sieling PA, Lee DJ (2014), Microbial dysbiosis is associated with human breast cancer. PLoS One 9, e83744.

153. Yazdi HR, Movafagh A, Fallah F, Alizadeh Shargh S, Mansouri N, Heidary Pour A, Hashemi M (2016), Evaluation of Methylobacterium radiotolerance and Sphyngomonas yanoikoaie in sentinel lymph nodes of breast cancer cases. Asian Pac J Cancer Prev 17, 279-285.

154. Velicer CM, Heckbert SR, Lampe JW, Potter JD, Robertson CA, Taplin SH (2004), Antibiotic use in relation to the risk of breast cancer. JAMA 291, 827-835.

155. Wang H, Altemus J, Niazi F, Green H, Calhoun BC, Sturgis C, Grobmyer SR, Eng C (2017), Breast tissue, oral and urinary microbiomes in breast cancer. Oncotarget 8 , $88122-88138$.

156. Kutschera U (2007), Plant-associated methylobacteria as co-evolved phytosymbionts: a hypothesis. Plant Signal Behav 2, 74-78.

157. Lai CC, Cheng A, Liu WL, Tan CK, Huang YT, Chung KP, Lee MR, Hsueh PR (2011), Infections caused by unusual Methylobacterium species. J Clin Microbiol 49, 3329-3331.

158. Ishii Y, Sakai S, Honma Y (2003), Cytokinin-induced differentiation of human myeloid leukemia HL-60 cells is associated with the formation of nucleotides, but not with incorporation into DNA or RNA. Biochim Biophys Acta 1643, 11-24.

159. Pollock CB, Koltai H, Kapulnik Y, Prandi C, Yarden RI (2012), Strigolactones: a novel class of phytohormones that inhibit the growth and survival of breast cancer cells and breast cancer stem-like enriched mammosphere cells. Breast Cancer Res Treat 134, 1041-1055.

160. Purcell RV, Pearson J, Aitchison A, Dixon L, Frizelle FA, Keenan JI (2017), Colonization with enterotoxigenic Bacteroides fragilis is associated with early-stage colorectal neoplasia. PLoS One 12, e0171602.

161. Dejea CM, Wick EC, Hechenbleikner EM, White JR, Mark Welch JL, Rossetti BJ, Peterson SN, Snesrud EC, Borisy GG, Lazarev M, Stein E, Vadivelu J, Roslani AC, Malik AA, Wanyiri JW, Goh KL, Thevambiga I, Fu K, Wan F, Llosa N, Housseau F, Romans K, Wu X, McAllister FM, Wu S, Vogelstein B, Kinzler KW, Pardoll DM, Sears CL (2014), Microbiota organization is a distinct feature of proximal colorectal cancers. Proc Natl Acad Sci USA 111, 18321-18326.

162. Burns MB, Lynch J, Starr TK, Knights D, Blekhman R (2015), Virulence genes are a signature of the microbiome in the colorectal tumor microenvironment. Genome Med $7,1-12$.

163. Wu LC, Sun PL, Chang YT (2013), Extensive deep dermatophytosis caused by Trichophyton rubrum in a patient with liver cirrhosis and chronic renal failure. Mycopathologia 176, 457-462.

164. Poonawalla T, Chen W, Duvic M (2006), Mycosis fungoides with tinea pseudoimbricata owing to Trichophyton rubrum infection. J Cutan Med Surg 10, 52-56.

165. Zhang B, Izadjoo M, Horkayne-Szakaly I, Morrison A, Wear DJ (2011), Medulloblastoma and Brucellosis: molecular evidence of Brucella sp in association with central nervous system cancer. J Cancer 2, 136-141.

166. Ye X, Wang R, Bhattacharya R, Boulbes DR, Fan F, Xia L, Adoni H, Ajami NJ, Wong MC, Smith DP, Petrosino JF, Venable S, Qiao W, Baladandayuthapani V, Maru D, Ellis LM (2017), Fusobacterium nucleatum subspecies animalis influences proinflammatory cytokine expression and monocyte activation in human colorectal tumors. Cancer Prev Res (Phila) 10, 398-409. 
167. Swidnicka-Siergiejko AK, Gomez-Chou SB, CruzMonserrate Z, Deng D, Liu Y, Huang H, Ji B, Azizian N, Daniluk J, Lu W, Wang H, Maitra A, Logsdon CD (2017), Chronic inflammation initiates multiple forms of K-Ras-independent mouse pancreatic cancer in the absence of TP53. Oncogene 36, 3149-3158.

168. Thamavit W, Bhamarapravati N, Sahaphong S, Vajrasthira S, Angsubhakorn S (1978), Effects of dimethylnitrosamine on induction of cholangiocarcinoma in Opisthorchis viverrini-infected Syrian golden hamsters. Cancer Res 38, 4634-4639.

169. Sonakul D, Koompirochana C, Chinda K, Stitnimakarn T (1978), Hepatic carcinoma with opisthorchiasis. Southeast Asian J Trop Med Public Health 9, 215-219.

170. Young ND, Nagarajan N, Lin SJ, Korhonen PK, Jex AR, Hall RS, Safavi-Hemam, H, Kaewkong W, Bertrand D, Gao S, Seet Q, Wongkham S, Teh BT, Wongkham C, Intapan PM, Maleewong W, Yang X, Hu M, Wang Z, Hofmann A, Sternberg PW, Tan P, Wang J, Gasser RB (2014), The Opisthorchis viverrini genome provides insights into life in the bile duct. Nat Commun 5, 4378.

171. Sripa B, Pairojkul C (2008), Cholangiocarcinoma: lessons from Thailand. Curr Opin Gastroenterol 24, 349-356.

172. Vonghachack Y, Odermatt P, Taisayyavong K, Phounsavath S, Akkhavong K, Sayasone S (2017), Transmission of Opisthorchis viverrini, Schistosoma mekongi and soiltransmitted helminthes on the Mekong Islands, Southern Lao PDR. Infect Dis Poverty 6, 131.

173. Dechakhamphu S, Pinlaor S, Sitthithaworn P, Nair J, Bartsch H, Yongvanit P (2010), Lipid peroxidation and etheno DNA adducts in white blood cells of liver flukeinfected patients: protection by plasma alpha-tocopherol and praziquantel. Cancer Epidemiol Biomarkers Prev 19, 310-318.

174. Gouveia MJ, Pakharukova MY, Laha T, Sripa B, Maksimova GA, Rinaldi G, Brindley PJ, Mordvinov VA, Amaro T, Santos LL, Costa JMCD, Vale N (2017), Infection with Opisthorchis felineus induces intraepithelial neoplasia of the biliary tract in a rodent model. Carcinogenesis 38, 929-937.

175. Wongsena W, Charoensuk L, Dangtakot R, Pinlaor P, Intuyod K, Pinlaor S (2017), Melatonin suppresses eosinophils and Th17 cells in hamsters treated with a combination of human liver fluke infection and a chemical carcinogen. Pharmacol Rep 70, 98-105.

176. Tartour E, Fossiez F, Joyeux I, Galinha A, Gey A, Claret E, Sastre-Garau X, Couturier J, Mosseri V, Vives V, Banchereau J, Fridman WH, Wijdenes J, Lebecque S, Sautès-Fridman C (1999), Interleukin 17, a T-cell-derived cytokine, promotes tumorigenicity of human cervical tumors in nude mice. Cancer Res 59, 3698-3704.

177. Kato T, Furumoto H, Ogura T, Onishi Y, Irahara M, Yamano S, Kamada M, Aono T (2001), Expression of IL-17 mRNA in ovarian cancer. Biochem Biophys Res Commun 282, 735-738.

178. Benchetrit F, Ciree A, Vives V, Warnier G, Gey A, SautèsFridman C, Fossiez F, Haicheur N, Fridman WH, Tartour E (2002), Interleukin-17 inhibits tumor cell growth by means of a T-cell-dependent mechanism. Blood 99, 21142121.

179. Wägsäter D, Löfgren S, Hugander A, Dimberg J (2006), Expression of interleukin-17 in human colorectal cancer. Anticancer Res 26, 4213-4216.

180. Changchun K, Pengchao H, Ke S, Ying W, Lei W (2017), Interleukin-17 augments tumor necrosis factor $\alpha$-mediated increase of hypoxia-inducible factor- $1 \alpha$ and inhibits vasodilator-stimulated phosphoprotein expression to reduce the adhesion of breast cancer cells. Oncol Lett 13 , 3253-3260.

181. Ma M, Huang W, Kong D (2018), IL-17 inhibits the accumulation of myeloid-derived suppressor cells in breast cancer via activating STAT3. Int Immunopharmacol 59, $148-156$.

182. Steiner GE, Newman ME, Paikl D, Stix U, MemaranDagda N, Lee C, Marberger MJ (2003), Expression and function of pro-inflammatory interleukin IL-17 and IL-17 receptor in normal, benign hyperplastic, and malignant prostate. Prostate 56, 171-182.

183. Numasaki M, Watanabe M, Suzuki T, Takahashi H, Nakamura A, McAllister F, Hishinuma T, Goto J, Lotze MT, Kolls JK, Sasaki H (2005), IL-17 enhances the net angiogenic activity and in vivo growth of human non-small cell lung cancer in SCID mice through promoting CXCR-2-dependent angiogenesis. J Immunol 175, 6177-6189.

184. Li G, Zhang Y, Qian Y, Zhang H, Guo S, Sunagawa M, Hisamitsu T, Liu Y (2013), Interleukin-17A promotes rheumatoid arthritis synoviocytes migration and invasion under hypoxia by increasing MMP2 and MMP9 expression through NF-кB/HIF-1 $\alpha$ pathway. Mol Immunol 53, $227-236$.

185. Obradović H, Krstić J, Kukolj T, Trivanović D, Đorđević IO, Mojsilović S, Jauković A, Jovčić G, Bugarski D, Santibañez JF (2016), Doxycycline inhibits IL-17-stimulated MMP-9 expression by downregulating ERK1/2 activation: implications in myogenic differentiation. Mediators Inflamm 2016, 2939658.

186. Park MJ, Moon SJ, Lee EJ, Jung KA, Kim EK, Kim DS, Lee JH, Kwok SK, Min JK, Park SH, Cho ML (2018), IL-1IL-17 signaling axis contributes to fibrosis and inflammation in two different murine models of systemic sclerosis. Front Immunol 9, 1611.

187. Chang SL, Hsiao YW, Tsai YN, Lin SF, Liu SH, Lin YJ, Lo LW, Chung FP, Chao TF, Hu YF, Tuan TC, Liao JN, Hsieh YC, Wu TJ, Higa S, Chen SA (2018), Interleukin-17 enhances cardiac ventricular remodeling via activating MAPK pathway in ischemic heart failure. J Mol Cell Cardiol 122, 69-79.

188. Zhang Y, Zhang YY, Li TT, Wang J, Jiang Y, Zhao Y, Jin XX, Xue GL, Yang Y, Zhang XF, Sun YY, Zhang ZR, Gao X, Du ZM, Lu YJ, Yang BF, Pan ZW (2018), Ablation of interleukin-17 alleviated cardiac interstitial fibrosis and improved cardiac function via inhibiting long non-coding RNA-AK081284 in diabetic mice. J Mol Cell Cardiol 115, 64-72.

189. Mehrotra P, Collett JA, Gunst SJ, Basile DP (2018), Th17 cells contribute to pulmonary fibrosis and inflammation during chronic kidney disease progression after acute ischemia. Am J Physiol Regul Integr Comp Physiol 314, R265- R273.

190. Sun B, Wang H, Zhang L, Yang X, Zhang M, Zhu X, Ji X, Wang H (2018), Role of interleukin 17 in TGF- $\beta$ signalingmediated renal interstitial fibrosis. Cytokine 106, $80-88$.

191. Mohamed R, Jayakumar C, Chen F, Fulton D, Stepp D, Gansevoort RT, Ramesh G (2016), Low-Dose IL-17 therapy prevents and reverses diabetic nephropathy, metabolic syndrome, and associated organ fibrosis. J Am Soc Nephrol 27, 745-765.

192. Kinyanjui MW, Shan J, Nakada EM, Qureshi ST, Fixman ED (2013), Dose-dependent effects of IL-17 on IL-13induced airway inflammatory responses and airway hyperresponsiveness. J Immunol 190, 3859-3868. 
193. Krueger JG, Fretzin S, Suárez-Fariñas M, Haslett PA, Phipps KM, Cameron GS, McColm J, Katcherian A, Cueto I, White T, Banerjee S, Hoffman RW (2012), IL$17 \mathrm{~A}$ is essential for cell activation and inflammatory gene circuits in subjects with psoriasis. J Allergy Clin Immunol 130, 145-154.

194. Chen E, Cen Y, Lu D, Luo W, Jiang H (2018), IL-22 inactivates hepatic stellate cells via downregulation of the TGF- $\beta 1 /$ notch signaling pathway. Mol Med Rep 17, 5449-5453.

195. Ye J, Liu L, Ji Q, Huang Y, Shi Y, Shi L, Liu J, Wang M, Xu Y, Jiang H, Wang Z, Lin Y, Wan J (2017), Antiinterleukin-22-neutralizing antibody attenuates angiotensin II-induced cardiac hypertrophy in mice. Mediators Inflamm 2017, 5635929.

196. Rattik S, Hultman K, Rauch U, Söderberg I, Sundius L, Ljungcrantz I, Hultgårdh-Nilsson A, Wigren M, Björkbacka H, Fredrikson GN, Nilsson J (2015), IL-22 affects smooth muscle cell phenotype and plaque formation in apolipoprotein E knockout mice. Atherosclerosis 242, 506-514.

197. Molina MF, Abdelnabi MN, Fabre T, Shoukry NH (2018), Type 3 cytokines in liver fibrosis and liver cancer. Cytokine, pii: S1043-4666(18)30326-0.

198. Li H, Li G, Liu L, Guo Z, Ma X, Cao N, Lin H, Han G, Duan Y, Du G (2015), Tumor interstitial fluid promotes malignant phenotypes of lung cancer independently of angiogenesis. Cancer Prev Res (Phila) 8, 1120-1129.

199. Xia J, Wang H, Li S, Wu Q, Sun L, Huang H, Zeng M (2017), Ion channels or aquaporins as novel molecular targets in gastric cancer. Mol Cancer 16, 54 .

200. Görgülü K, Diakopoulos KN, Ai J, Schoeps B, Kabacaoglu D, Karpathaki AF, Ciecielski KJ, Kaya-Aksoy E, Ruess DA, Berninger A, Kowalska M, Stevanovic M, Wörmann SM, Wartmann T, Zhao Y, Halangk W, Voronina S, Tepikin A, Schlitter AM, Steiger K, Artati A, Adamski J, Aichler M, Walch A, Jastroch M, Hartleben G, Mantzoros CS, Weichert W, Schmid RM, Herzig S, Krüger A, Sainz B Jr, Lesina M,Algül H (2018), Levels of the autophagy related 5 protein affect progression and metastasis of pancreatic tumors in mice. Gastroenterology, pii: S00165085(18)35087-X.

201. Preston GM, Carroll TP, Guggino WB, Agre P (1992), Appearance of water channels in Xenopus oocytes expressing red cell CHIP28 protein. Science 256, 385-387.

202. Rojek A, Füchtbauer EM, Kwon TH, Frøkiaer J, Nielsen S (2006), Severe urinary concentrating defect in renal collecting duct-selective AQP2 conditional-knockout mice. Proc Natl Acad Sci USA 103, 6037-6042.

203. Rojek AM, Skowronski MT, Füchtbauer EM, Füchtbauer AC, Fenton RA, Agre P, Frøkiaer J, Nielsen S (2007), Defective glycerol metabolism in aquaporin 9 (AQP9) knockout mice. Proc Natl Acad Sci USA 104, 3609-3614.

204. Méndez-Giménez L, Rodríguez A, Balaguer I, Frühbeck G (2014), Role of aquaglyceroporins and caveolins in energy and metabolic homeostasis. Mol Cell Endocrinol 397, 78-92.

205. Madeira A, Moura TF, Soveral G (2015), Aquaglyceroporins: implications in adipose biology and obesity. Cell Mol Life Sci 72, 759-771.

206. Verkman AS (2005), More than just water channels: unexpected cellular roles of aquaporins. J Cell Sci 118, 3225-3232.

207. Cerdà J, Finn RN (2010), Piscine aquaporins: an overview of recent advances. J Exp Zool A Ecol Genet Physiol 313, 623-650.
208. Saadoun S, Papadopoulos MC, Davies DC, Bell BA, Krishna S (2002), Increased aquaporin 1 water channel expression in human brain tumours. Br $\mathrm{J}$ Cancer 87, 621-623.

209. Saadoun S, Papadopoulos MC, Hara-Chikuma M, Verkman AS (2005), Impairment of angiogenesis and cell migration by targeted aquaporin-1 gene disruption. Nature 434, 786-792.

210. Jung HJ, Park JY, Jeon HS, Kwon TH (2011), Aquaporin5: a marker protein for proliferation and migration of human breast cancer cells. PLoS One 6, e28492.

211. Chen J, Wang T, Zhou YC, Gao F, Zhang ZH, Xu H, Wang SL, Shen LZ (2014), Aquaporin 3 promotes epithelial-mesenchymal transition in gastric cancer. J Exp Clin Cancer Res 33, 38.

212. Lee SJ, Chae YS, Kim JG, Kim WW, Jung JH, Park HY, Jeong JY, Park JY, Jung HJ, Kwon TH (2014), AQP5 expression predicts survival in patients with early breast cancer. Ann Surg Oncol 21, 375-383.

213. Stroka KM, Jiang H, Chen SH, Tong Z, Wirtz D, Sun SX, Konstantopoulos K (2014), Water permeation drives tumor cell migration in confined microenvironments. Cell 157, 611-623.

214. Papadopoulos MC, Saadoun S (2015), Key roles of aquaporins in tumor biology. Biochim Biophys Acta 1848, 2576-2583.

215. Verkman AS, Hara-Chikuma M, Papadopoulos MC (2008), Aquaporins: new players in cancer biology. J Mol Med (Berl) 86, 523-529.

216. Papadopoulos MC, Saadoun S, Verkman AS (2008), Aquaporins and cell migration. Pflugers Arch 456, 693-700.

217. Mola MG, Nicchia GP, Svelto M, Spray DC, Frigeri A (2009), Automated cell-based assay for screening of aquaporin inhibitors. Anal Chem 81, 8219-8229.

218. Venglovecz V, Pallagi P, Kemény LV, Balázs A, Balla Z, Becskeházi E, Gál E, Tóth E, Zvara Á, Puskás LG, Borka K, Sendler M, Lerch MM, Mayerle J, Kühn JP, Rakonczay Z Jr, Hegyi P (2018), The importance of aquaporin 1 in pancreatitis and its relation to the CFTR Cl- channel. Front Physiol 9, 854.

219. Trujillo E, González T, Marín R, Martín-Vasallo P, Marples D, Mobasheri A (2004), Human articular chondrocytes, synoviocytes and synovial microvessels express aquaporin water channels: upregulation of AQP1 in rheumatoid arthritis. Histol Histopathol 19, 435-444.

220. Hardin JA, Wallace LE, Wong JF, O'Loughlin EV, Urbanski SJ, Gall DG, MacNaughton WK, Beck PL (2004), Aquaporin expression is downregulated in a murine model of colitis and in patients with ulcerative colitis, Crohn's disease and infectious colitis. Cell Tissue Res 318, 313-323.

221. Ricanek P, Lunde LK, Frye SA, Støen M, Nygård S, Morth JP, Rydning A, Vatn MH, Amiry-Moghaddam M, Tønjum T (2015), Reduced expression of aquaporins in human intestinal mucosa in early stage inflammatory bowel disease. Clin Exp Gastroenterol 8, 49-67.

222. Brücher BLDM, Jamall IS (2019), Eicosanoids in carcinogenesis. 4open 2, 9, 1-34, https://doi.org/10.1051/fopen/ 2018008

223. Shi Z, Ye W, Zhang J, Zhang F, Yu D, Yu H, Chen B, Zhou M, Sun H (2018), LipoxinA4 attenuates acute pancreatitis-associated acute lung injury by regulating AQP-5 and MMP-9 expression, anti-apoptosis and $\mathrm{PKC} / \mathrm{SSeCKS}-\mathrm{mediated} \mathrm{F}$-actin activation. Mol Immunol 103, 78-88. 
224. Watanabe T, Fujii T, Oya T, Horikawa N, Tabuchi Y, Takahashi Y, Morii M, Takeguchi N, Tsukada K, Sakai H (2009), Involvement of aquaporin-5 in differentiation of human gastric cancer cells. J Physiol Sci 59, 113-122.

225. Gao L, Gao Y, Li X, Howell P, Kumar R, Su X, Vlassov AV, Piazza GA, Riker AI, Sun D, Xi Y (2012), Aquaporins mediate the chemoresistance of human melanoma cells to arsenite. Mol Oncol 6, 81-87.

226. Burghardt B, Elkaer ML, Kwon TH, Rácz GZ, Varga G, Steward MC, Nielsen S (2003), Distribution of aquaporin water channels AQP1 and AQP5 in the ductal system of the human pancreas. Gut 52, 1008-1016.

227. Kang SK, Chae YK, Woo J, Kim MS, Park JC, Lee J, Soria JC, Jang SJ, Sidransky D, Moon C (2008), Role of human aquaporin 5 in colorectal carcinogenesis. Am J Pathol 173, 518-525.

228. Direito I, Paulino J, Vigia E, Brito MA, Soveral G (2017), Differential expression of aquaporin-3 and aquaporin-5 in pancreatic ductal adenocarcinoma. J Surg Oncol 115, 980-996.

229. Klionsky DJ (2008), Autophagy revisited: a conversation with Christian de Duve. Autophagy 4, 740-743.

230. de Reuck AVS, Cameron MP (1963), Ciba Foundation Symposium on Lysosomes, London on February 12-14, J. A. Churchill Ltd, 1963. http://www.tandfonline.com/ doi/pdf/10.4161/auto.6398?needAccess $=$ true

231. Blazkova H, Krejcikova K, Moudry P, Frisan T, Hodny Z, Bartek J (2010), Bacterial intoxication evokes cellular senescence with persistent DNA damage and cytokine signaling. J Cell Mol Med 14, 357-367.

232. Nakamura T, Furukawa A, Uchida K, Ogawa T, Tamura T, Sakonishi D, Wada Y, Suzuki Y, Ishige Y, Minami J, Akashi T, Eishi Y (2016), Autophagy induced by intracellular infection of Propionibacterium acnes. PLoS One 11, e0156298.

233. Tattoli I, Sorbara MT, Philpott DJ, Girardin SE (2012), Bacterial autophagy, the trigger, the target and the timing. Autophagy 8, 1848-1850.

234. Wang YH, Wu JJ, Lei HY (2009), The autophagic induction in Helicobacter pylori-infected macrophage. Exp Biol Med (Maywood) 234, 171-180.

235. Zhirnov OP (2017), Biochemical variations in cytolytic activity of ortho- and paramyxoviruses in human lung tumor cell culture. Biochemistry (Mosc) 82, 1048-1054.

236. Dou Z, Ghosh K, Vizioli MG, Zhu J, Sen P, Wangensteen KJ, Simithy J, Lan Y, Lin Y, Zhou Z, Capell BC, Xu C, Xu M, Kieckhaefer JE, Jiang T, Shoshkes-Carmel M, Tanim KMAA, Barber GN, Seykora JT, Millar SE, Kaestner KH, Garcia BA, Adams PD, Berger SL (2017), Cytoplasmic chromatin triggers inflammation in senescence and cancer. Nature 550, 402-406.

237. Lauretti E, Iuliano L, Praticò D (2017), Extra-virgin olive oil ameliorates cognition and neuropathology of the $3 \mathrm{xTg}$ mice: role of autophagy. Ann Clin Transl Neurol 4, 564-574.

238. Pott J, Maloy KJ (2018), Epithelial autophagy controls chronic colitis by reducing TNF-induced apoptosis. Autophagy 14, 1460-1461.

239. Grizotte-Lake M, Vaishnava S (2018), Autophagy: suicide prevention hotline for the gut epithelium. Cell Host Microbe 23, 147-148.

240. Lerch MM, Gorelick FS (2013), Models of acute and chronic pancreatitis. Gastroenterology 144, 1180-1193.

241. Pinho AV, Chantrill L, Rooman I (2014), Chronic pancreatitis: a path to pancreatic cancer. Cancer Lett 345, 203-209.
242. Jiao F, Hu H, Yuan C, Wang L, Jiang W, Jin Z, Guo Z, Wang L (2014), Elevated expression level of long noncoding RNA MALAT-1 facilitates cell growth, migration and invasion in pancreatic cancer. Oncol Rep 32, 2485-2492.

243. Pang EJ, Yang R, Fu XB, Liu YF (2015), Overexpression of long non-coding RNA MALAT1 is correlated with clinical progression and unfavorable prognosis in pancreatic cancer. Tumour Biol 36, 2403-2407.

244. Li L, Chen H, Gao Y, Wang YW, Zhang GQ, Pan SH, Ji L, Kong R, Wang G, Jia YH, Bai XW, Sun B (2016), Long noncoding RNA MALAT1 promotes aggressive pancreatic cancer proliferation and metastasis via the stimulation of autophagy. Mol Cancer Ther 15, 2232-2243.

245. Li L, Wang G, Hu JS, Zhang GQ, Chen HZ, Yuan Y, Li YL, Lv XJ, Tian FY, Pan SH, Bai XW, Sun B (2018), RB1CC1-enhanced autophagy facilitates PSCs activation and pancreatic fibrogenesis in chronic pancreatitis. Cell Death Dis 9, 952.

246. Liu J, Wang X, Zheng M, Luan Q (2018), Lipopolysaccharide from Porphyromonas gingivalis promotes autophagy of human gingival fibroblasts through the PI3K/Akt/mTOR signaling pathway. Life Sci 211, 133-139.

247. Ma Y, Pei Q, Zhang L, Lu J, Shui T, Chen J, Shi C, Yang J, Smith M, Liu Y, Zhu J, Yang D (2018), Live Mycobacterium leprae inhibits autophagy and apoptosis of infected macrophages and prevents engulfment of host cell by phagocytes. Am J Transl Res 10, 2929-2939.

248. Brech A, Ahlquist T, Lothe RA, Stenmark H (2009), Autophagy in tumour suppression and promotion. Mol Oncol 3, 366-375.

249. Gukovskaya AS, Gukovsky I, Algül H, Habtezion A (2017), Autophagy, inflammation, and immune dysfunction in the pathogenesis of pancreatitis. Gastroenterology $153,1212-1226$.

250. Fadok VA, Bratton DL, Konowal A, Freed PW, Westcott JY, Henson PM (1998), Macrophages that have ingested apoptotic cells in vitro inhibit proinflammatory cytokine production through autocrine/paracrine mechanisms involving TGF-beta, PGE2, and PAF. J Clin Invest 101, 890-898.

251. Metz M, Grimbaldeston MA, Nakae S, Piliponsky AM, Tsai M, Galli SJ (2007), Mast cells in the promotion and limitation of chronic inflammation. Immunol Rev 217, 304-328.

252. Wynn TA, Ramalingam TR (2012), Mechanisms of fibrosis: therapeutic translation for fibrotic disease. Nat Med 18, 1028-1040.

253. Hartupee J, Mann DL (2016), Role of inflammatory cells in fibroblast activation. J Mol Cell Cardiol 93, 143-148.

254. Parameswaran N, Patial S (2010), Tumor necrosis factor$\alpha$ signaling in macrophages. Crit Rev Eukaryot Gene Expr 20, 87-103.

255. Mirza RE, Fang MM, Ennis WJ, Koh TJ (2013), Blocking interleukin-1 $\beta$ induces a healing-associated wound macrophage phenotype and improves healing in type 2 diabetes. Diabetes 62, 2579-2587.

256. Zhang X, Li J, Qin JJ, Cheng WL, Zhu X, Gong FH, She Z, Huang Z, Xia H, Li H (2017), Oncostatin M receptor $\beta$ deficiency attenuates atherogenesis by inhibiting JAK2/ STAT3 signaling in macrophages. J Lipid Res 58, 895906.

257. Kalluri R (2016), The biology and function of fibroblasts in cancer. Nat Rev Cancer 16, 582-598. 
258. Monaco C, Andreakos E, Young S, Feldmann M, Paleolog E (2002), T cell-mediated signaling to vascular endothelium: induction of cytokines, chemokines, and tissue factor. J Leukoc Biol 71, 659-668.

259. Guo Q, Minnier J, Burchard J, Chiotti K, Spellman P, Schedin P (2017), Physiologically activated mammary fibroblasts promote postpartum mammary cancer. JCI Insight 2, e89206.

260. Dai W, Gupta SL (1990), Molecular cloning, sequencing and expression of human interferon-gamma-inducible indoleamine 2,3-dioxygenase cDNA. Biochem Biophys Res Commun 168, 1-8.

261. Uyttenhove C, Pilotte L, Theate I, Stroobant V, Colau D, Parmentier N, Boon T, Van den Eynde BJ (2003), Evidence for a tumoral immune resistance mechanism based on tryptophan degradation by indoleamine 2, 3dioxygenase. Nat Med 9, 1269-1274.

262. Witkiewicz A, Williams TK, Cozzitorto J, Durkan B, Showalter SL, Yeo CJ, Brody JR (2008), Expression of indoleamine 2, 3-dioxygenase in metastatic pancreatic ductal adenocarcinoma recruits regulatory $\mathrm{T}$ cells to avoid immune detection. J Am Coll Surg 206, 849-854.

263. Zhang T, Tan XL, Xu Y, Wang ZZ, Xiao CH, Liu R (2017), Expression and prognostic value of indoleamine 2,3dioxygenase in pancreatic cancer. Chin Med J (Engl) $130,710-716$.

264. Löb S, Königsrainer A, Zieker D, Brücher BLDM, Rammensee HG, Oplez G, Terness P (2009), IDO1 and IDO2 are expressed in human tumors: levo- but not dextro-1-methyl tryptophan inhibits tryptophan catabolism. Cancer Immunol Immun 58, 153-157.

265. El-Zaatari M, Bass AJ, Bowlby R, Zhang M, Syu LJ, Yang Y, Grasberger H, Shreiner A, Tan B, Bishu S, Leung WK, Todisco A, Kamada N, Cascalho M, Dlugosz AA, Kao JY (2017), Indoleamine 2,3-dioxygenase 1, increased in human gastric pre-neoplasia, promotes inflammation and metaplasia in mice and is associated with type II hypersensitivity/autoimmunity. Gastroenterology, pii: S0016-5085(17)36137-1.

266. Brandacher G, Perathoner A, Ladurner R, Schneeberger S, Obrist P, Winkler C, Werner ER, Werner-Felmayer G, Weiss HG, Gobel G, Margreiter R, Konigsrainer A, Fuchs D, Amberger A (2006), Prognostic value of indoleamine 2,3-dioxygenase expression in colorectal cancer: eVect on tumor-infiltrating T cells. Clin Cancer Res 12, 1144-1151.

267. Travers MT, Gow IF, Barber MC, Thomson J, Shennan DB (2004), Indoleamine 2,3-dioxygenase activity and l-tryptophan transport in human breast cancer cells. Biochim Biophys Acta 1661, 106-112.

268. Okamoto A, Nikaido T, Ochiai K, Takakura S, Saito M, Aoki Y, Ishii N, Yanaihara N, Yamada K, Takikawa O, Kawaguchi R, Isonishi S, Tanaka T, Urashima M (2005), Indoleamine 2,3-dioxygenase serves as a marker of poor prognosis in gene expression profiles of serous ovarian cancer cells. Clin Cancer Res 11, 6030-6039.

269. Ino K, Yoshida N, Kajiyama H, Shibata K, Yamamoto E, Kidokoro K, Takahashi N, Terauchi M, Nawa A, Nomura S, Nagasaka T, Takikawa O, Kikkawa F (2006), Indoleamine 2,3-dioxygenase is a novel prognostic indicator for endometrial cancer. Br J Cancer 95, 1555-1561.

270. Metz R, Duhadaway JB, Rust S, Munn DH, Muller AJ, Mautino M, Prendergast GC (2010), Zinc protoporphyrin IX stimulates tumor immunity by disrupting the immunosuppressive enzyme indoleamine 2,3-dioxygenase. Mol Cancer Ther 9, 1864-1871.

271. Popper H (1977), Pathologic aspects of cirrhosis: a review. Am J Pathol 87, 228-264.
272. Larriba MJ, Ordóñez-Morán P, Chicote I, MartínFernández G, Puig I, Muñoz A, Pálmer HG (2011), Vitamin D receptor deficiency enhances Wnt/ $\beta$-catenin signaling and tumor burden in colon cancer. PLoS One 6 , e23524.

273. Csepregi A, Röcken C, Hoffmann J, Gu P, Saliger S, Müller O, Schneider-Stock R, Kutzner N, Roessner A, Malfertheiner P, Ebert MP (2008), APC promoter methylation and protein expression in hepatocellular carcinoma. J Cancer Res Clin Oncol 134, 579-589.

274. Rexhepaj R, Rotte A, Gu S, Michael D, Pasham V, Wang K, Kempe DS, Ackermann TF, Brücher BLDM, Fend F, Föller M, Lang F (2011), Tumor suppressor gene adenomatous polyposis coli downregulates intestinal transport. Pflug Arch 461, 527-536.

275. Agüera-González S, Burton OT, Vázquez-Chávez E, Cuche C, Herit F, Bouchet J, Lasserre R, Del Río-Iñiguez I, Di Bartolo V, Alcover A (2017), Adenomatous polyposis coli defines treg differentiation and anti-inflammatory function through microtubule-mediated NFAT localization. Cell Rep 21, 181-194.

276. Ekman M, Mu Y, Lee SY, Edlund S, Kozakai T, Thakur N, Tran H, Qian J, Groeden J, Heldin CH, Landström M (2012), APC and Smad7 link TGF $\beta$ type I receptors to the microtubule system to promote cell migration. Mol Biol Cell 23, 2109-2121.

277. Ashida N, Kishihata M, Tien DN, Kamei K, Kimura T, Yokode M (2014), Aspirin augments the expression of adenomatous polyposis coli protein by suppression of IKKbeta. Biochem Biophys Res Commun 446, 460-464.

278. Zeineldin M, Neufeld KL (2015), New insights from animal models of colon cancer: inflammation control as a new facet on the tumor suppressor APC gem. Gastrointest Cancer 5, 39-52.

279. Spirio L, Otterud B, Stauffer D, Lynch H, Lynch P, Watson P, Lanspa S, Smyrk T, Cavalieri J, Howard L, Burt R, White R, Leppert M (1992), Linkage of a variant or attenuated form of adenomatous polyposis coli to the adenomatous polyposis coli (APC) locus. Am J Hum Genet 51, 92-100.

280. Powell SM, Zilz N, Beazer-Barclay Y, Bryan TM, Hamilton SR, Thibodeau SN, Vogelstein B, Kinzler KW (1992), APC mutations occur early during colorectal tumorigenesis. Nature 359, 235-237.

281. Moser AR, Pitot HC, Dove WF (1990), A dominant mutation that predisposes to multiple intestinal neoplasia in the mouse. Science 247, 322-324.

282. Terzić J, Grivennikov S, Karin E, Karin M (2010), Inflammation and colon cancer. Gastroenterology 138, 2101-2114.

283. Zeineldin M, Cunningham J, McGuinness W, Alltizer P, Cowley B, Blanchat B, Xu W, Pinson D, Neufeld KL (2012), A knock-in mouse model reveals roles for nuclear Apc in cell proliferation, Wnt signal inhibition and tumor suppression. Oncogene 31, 2423-2437.

284. Zeineldin M, Miller MA, Sullivan R, Neufeld KL (2014), Nuclear adenomatous polyposis coli suppresses colitisassociated tumorigenesis in mice. Carcinogenesis 35, 1881-1890.

285. Prosperi JR, Lue HH, Goss KH (2011), Dysregulation of the WNT pathway in solid tumors, in: G Kathleen, M Kahn (Eds.), Targeting the Wnt Pathway in Cancer, Springer, New York, pp. 81-128. ISBN 978-14419-8023-6.

286. Grødeland G, Fossum E, Bogen B (2015), Polarizing T and $\mathrm{B}$ cell responses by APC-targeted subunit vaccines. Front Immunol 6, 367. 
287. Van der Auwera I, Van Laere SJ, Van den Bosch SM, Van den Eynden GG, Trinh BX, van Dam PA, Colpaert CG, van Engeland M, Van Marck EA, Vermeulen PB, Dirix LY (2008), Aberrant methylation of the Adenomatous Polyposis Coli (APC) gene promoter is associated with the inflammatory breast cancer phenotype. Br J Cancer 99, 1735-1742.

288. Brabender J, Usadel H, Danenberg KD, Metzger R, Schneider PM, Lord RV, Wickramasinghe K, Lum CE, Park J, Salonga D, Singer J, Sidransky D, Hölscher AH, Meltzer SJ, Danenberg PV (2001), Adenomatous polyposis coli gene promoter hypermethylation in non-small cell lung cancer is associated with survival. Oncogene 20, $3528-3532$.

289. Usadel H, Brabender J, Danenberg KD, Jerónimo C, Harden S, Engles J, Danenberg PV, Yang S, Sidransky D (2002), Quantitative adenomatous polyposis coli promoter methylation analysis in tumor tissue, serum, and plasma DNA of patients with lung cancer. Cancer Res 62, 371-375.

290. Jeronimo C, Henrique R, Hoque MO, Mambo E, Ribeiro FR, Varzim G, Oliveira J, Teixeira MR, Lopes C, Sidransky D (2004), A quantitative promoter methylation profile of prostate cancer. Clin Cancer Res 10, 8472-8478.

291. Bastian PJ, Ellinger J, Wellmann A, Wernert N, Heukamp LC, Müller SC, von Ruecker A (2005), Diagnostic and prognostic information in prostate cancer with the help of a small set of hypermethylated gene loci. Clin Cancer Res 11, 4097-4106.

292. Yegnasubramanian S, Kowalski J, Gonzalgo ML, Zahurak M, Piantadosi S, Walsh PC, Bova GS, De Marzo AM, Isaacs WB, Nelson WG (2004), Hypermethylation of $\mathrm{CpG}$ islands in primary and metastatic human prostate cancer. Cancer Res 64, 1975-1986.

293. Debouki-Joudi S, Trifa F, Khabir A, Sellami-Boudawara T, Frikha M, Daoud J, Mokdad-Gargouri R (2017), CpG methylation of APC promoter $1 \mathrm{~A}$ in sporadic and familial breast cancer patients. Cancer Biomark 18, 133-141.

294. Schauer IG, Zhang J, Xing Z, Guo X, Mercado-Uribe I, Sood AK, Huang P, Liu J (2013), Interleukin-1ß promotes ovarian tumorigenesis through a p53/NF-кB-mediated inflammatory response in stromal fibroblasts. Neoplasia 15, 409-420.

295. Battat R, Kopylov U, Bessissow T, Bitton A, Cohen A, Jain A, Martel M, Seidman E, Afif W (2017), Association between ustekinumab trough concentrations and clinical, biomarker, and endoscopic outcomes in patients with Crohn's disease. Clin Gastroenterol Hepatol 15, 1427-1434.

296. Steenport M, Khan KM, Du B, Barnhard SE, Dannenberg AJ, Falcone DJ (2009), Matrix metalloproteinase (MMP)1 and MMP-3 induce macrophage MMP-9: evidence for the role of TNF-alpha and cyclooxygenase-2. J Immunol 183, 8119-8127.

297. Gong Y, Chippada-Venkata UD, Oh WK (2014), Roles of matrix metalloproteinases and their natural inhibitors in prostate cancer progression. Cancers (Basel) 6, 12981327.

298. Boström PJ, Ravanti L, Reunanen N, Aaltonen V, Söderström KO, Kähäri VM, Laato M (2000), Expression of collagenase-3 (matrix metalloproteinase-13) in transitional-cell carcinoma of the urinary bladder. Int J Cancer $88,417-423$.

299. Reunanen N, Kähäri VM (2000-2013), Matrix metalloproteinases in cancer cell invasion. Madame Curie Bioscience Database, Landes Bioscience, 2000-2013. Available at https://www.ncbi.nlm.nih.gov/books/ NBK6598/

300. Sternlicht MD1, Werb Z (2001), How matrix metalloproteinases regulate cell behavior. Annu Rev Cell Dev Biol 17, 463-516.

301. Lu P, Takai K, Weaver VM, Werb Z (2011), Extracellular matrix degradation and remodeling in development and disease. Cold Spring Harb Perspect Biol 3, pii: a005058.

302. Miyoshi A, Kitajima Y, Sumi K, Sato K, Hagiwara A, Koga Y, Miyazaki K (2004), Snail and SIPl increase cancer invasion by upregulating MMP family in hepatocellular carcinoma cells. Br J Cancer 22, 1265-1273.

303. Miyoshi A, Kitajima Y, Kido S, Shimonishi T, Matsuyama S, Kitahara K, Miyazaki K (2005), Snail accelerates cancer invasion by upregulating MMP expression and is associated with poor prognosis of hepatocellular carcinoma. Br J Cancer 2005, 92, 252-258.

304. Brücher BLDM, Jamall IS (2019), Undervalued ubiquitous proteins. 4open 2, 7, 1-13, https://doi.org/10.1051/ fopen $/ 2019002$

305. Brücher BLDM, Jamall IS (2019), Microbiome and morbid obesity increase pathogenic stimulus diversity. 4open 2, 10, 1-16, https://doi.org/10.1051/fopen/2018007

Cite this article as: Brücher BLDM, Jamall IS. (2019), Chronic inflammation evoked by pathogenic stimulus during carcinogenesis. 4open, 2, 8 . 